INTER NATIONAL MONETARY FUND

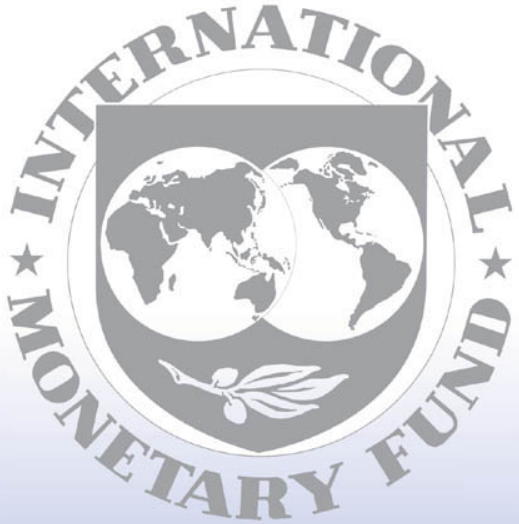

Staff

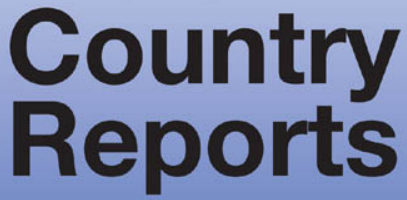




\title{
Iceland: 2007 Article IV Consultation-Staff Report; and Public Information Notice on the Executive Board Discussion
}

Under Article IV of the IMF's Articles of Agreement, the IMF holds bilateral discussions with members, usually every year. In the context of the 2007 Article IV consultation with Iceland, the following documents have been released and are included in this package:

- $\quad$ The staff report for the 2007 Article IV consultation, prepared by a staff team of the IMF, following discussions that ended on June 11, 2007, with the officials of Iceland on economic developments and policies. Based on information available at the time of these discussions, the staff report was completed on July 26, 2007. The views expressed in the staff report are those of the staff team and do not necessarily reflect the views of the Executive Board of the IMF.

- $\quad$ A Public Information Notice (PIN) summarizing the views of the Executive Board as expressed during its August 22, 2007 discussion of the staff report that concluded the Article IV consultation.

The document listed below has been or will be separately released.

Selected Issues Paper

The policy of publication of staff reports and other documents allows for the deletion of market-sensitive information.

To assist the IMF in evaluating the publication policy, reader comments are invited and may be sent by e-mail to publicationpolicy@imf.org.

\author{
Copies of this report are available to the public from \\ International Monetary Fund • Publication Services \\ $70019^{\text {th }}$ Street, N.W. • Washington, D.C. 20431 \\ Telephone: (202) 623-7430 • Telefax: (202) 623-7201 \\ E-mail: publications@imf.org •Internet: http://www.imf.org
}

Price: $\$ 18.00$ a copy

\section{International Monetary Fund \\ Washington, D.C.}


This page intentionally left blank 


\title{
INTERNATIONAL MONETARY FUND
}

\author{
ICELAND
}

\section{Staff Report for the 2007 Article IV Consultation}

\author{
Prepared by the Staff Representatives for the 2007 Consultation with Iceland
}

Approved by Alessandro Leipold and Carlo Cottarelli

July 26, 2007

\section{EXECUTIVE SUMMARY}

Background: Following three years of rapid economic expansion, some signs of slowing have emerged. However, large macroeconomic imbalances have built up and the projected return of private consumption to a sustainable level may be delayed. Icelandic banks have expanded rapidly, both at home and abroad, and firms, households, and the country, have become heavily indebted. Monetary policy tightened throughout the upswing, but mortgage market competition between the banks and the state-owned Housing Financing Fund (HFF), among other factors, limited its effectiveness. A large trading-partner-interest-rate differential has appreciated Iceland's freely floating currency and staff estimate current overvaluation to be 15-25 percent. Fiscal policy tightened as the economy expanded, but was eased in early 2007 . With core inflation outside the central bank's tolerance range, risks of renewed momentum in consumption, tight labor and goods markets, and much-diminished but large current account deficits likely to persist in the near term, discussions focused on the policies needed to quickly restore macroeconomic balance and ways to reduce future macroeconomic volatility.

Authorities' views: There were differences in views on the need for continued restraint. While the central bank noted that core inflation pressures remained strong with upside risks predominant, the fiscal authority anticipated economic slack appearing this year and inflation returning to target next year. While there was agreement that reforming the HFF would increase the effectiveness of monetary policy, it was noted that it could take several years to achieve. Merit was seen in further strengthening the fiscal framework and banks were viewed to have responded effectively to supervisor's and investors' concern in 2006.

Staff views: Given the risks in private consumption and absence of slack, additional restraint is necessary to re-anchor inflation at the target and ensure restoration of external balance. Fiscal policy will need to make a contribution and the HFF must be reformed quickly to increase the effectiveness of monetary policy. Along with other measures to ensure fiscal policy provides greater macroeconomic stabilization, spending ceilings need to be binding. The banking sector appears well-placed to withstand significant credit and market shocks. However, given the rapid expansion and increasing complexity of banks' businesses, continued vigilance and further development of stress testing and risk management techniques is crucial. Following the mission, initial steps were taken regarding the HFF and the central bank announced that policy would need to be tight for longer to achieve the inflation target. 


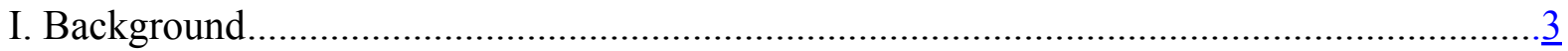

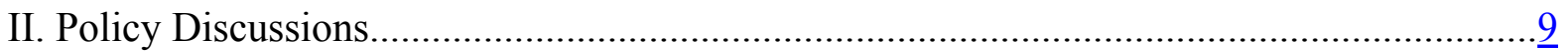

A. Outlook and Risks ..............................................................................

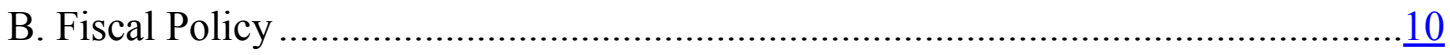

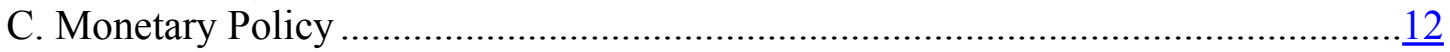

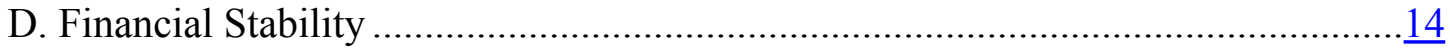

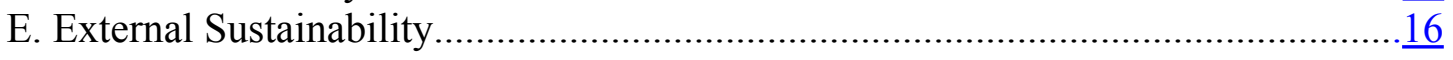

III. Staff Appraisal ................................................................................................ 17

Tables

1. Selected Economic Indicators, 2000-08 .................................................................... 19

2. Balance of Payments, 2000-12 .............................................................................. 20

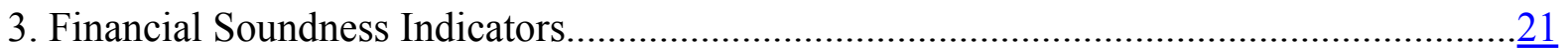

4. Summary Operations of the General Government, 2003-08 .........................................

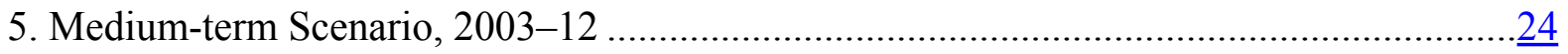

Figures

1. Rapid Economic Expansion with Mixed Signs of Slowing ............................................. $\underline{3}$

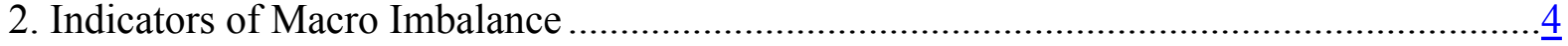

3. Limited Effectiveness of Monetary Policy ..................................................................... $\underline{6}$

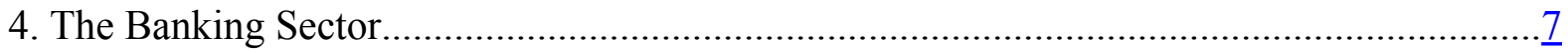

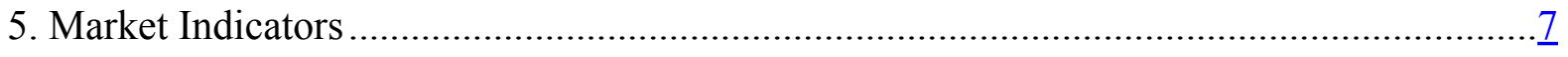

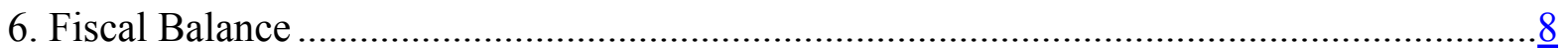

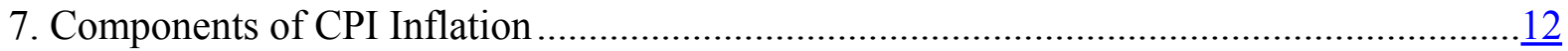

Boxes

1. Options for Reforming the Fiscal Framework ..........................................................11

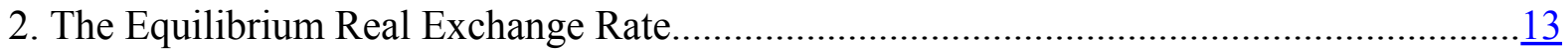

3. Króna-Denominated Eurobond Issues …......................................................... 15

Appendixes

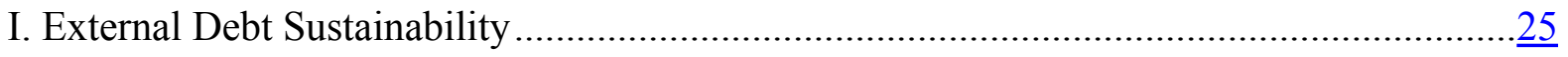




\section{BACKGROUND}

\section{After three years of rapid economic expansion, signs of a much-needed slowing} remain mixed. Aluminum-sector investment projects stimulated domestic demand, driving up the level of GDP by more than 20 percent over four years. Private consumption boomed as easing in household credit conditions, reductions in income taxes, rapidly rising housing and equity wealth, and relatively cheap imported consumption goods all coincided with favorable project-related employment and income prospects. With the bulk of the planned investments completed in 2006, the growth in private investment eased. Private

Quarterly GDP Growth, 2005-07 (y-o-y change, in percent)

\begin{tabular}{lccccccccc}
\hline & \multicolumn{9}{c}{2005} \\
& Q1 & Q2 & Q3 & Q4 & Q1 & Q2 & Q3 & Q4 & Q1 \\
\hline GDP & 3.4 & 10.1 & 9.9 & 5.2 & 5.1 & 2.6 & 0.5 & 2.5 & -0.1 \\
Domestic Demand & 11.0 & 13.2 & 22.0 & 15.6 & 14.8 & 10.0 & 2.6 & 3.2 & -9.6 \\
Private Consumption & 9.8 & 15.5 & 14.1 & 11.9 & 11.5 & 5.0 & 1.6 & 1.2 & -1.2 \\
Public Consumption & 2.9 & 3.8 & 3.4 & 4.8 & 3.2 & 2.5 & 2.9 & 2.9 & 2.2 \\
Investment & 23.2 & 24.7 & 47.6 & 39.4 & 36.3 & 18.4 & 1.5 & 3.4 & -28.4 \\
Exports & 2.1 & 21.6 & 3.4 & 2.6 & -0.8 & -7.3 & -7.0 & -6.4 & 16.9 \\
Imports & 24.1 & 27.3 & 34.4 & 30.6 & 26.8 & 12.8 & 0.4 & -0.6 & -11.9 \\
\hline
\end{tabular}
consumption growth also slowed, in part because of rising import prices from currency depreciation in early 2006. More recently, indicators suggest that the projected return of private consumption to a more sustainable level may be delayed. Cuts in taxes in the first half of 2007, currency strength, and renewed house price appreciation have restored consumer confidence.

Figure 1. Rapid Econonomic Expansion with Mixed Signs of Slowing
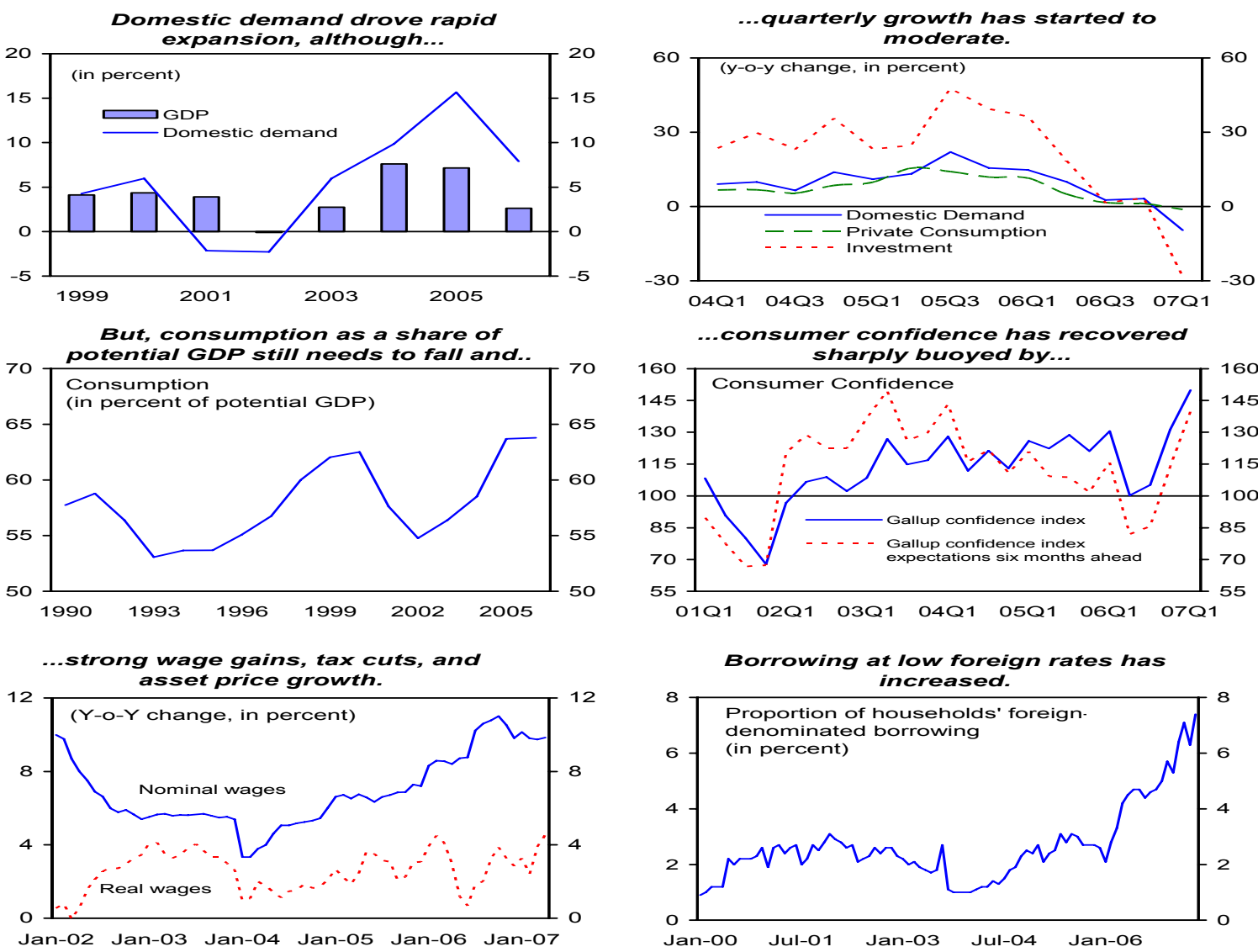
2. Record imbalances built up during the boom. The positive output gap is estimated to have reached over 5 percent in 2005, declining modestly to 31/2 percent in 2006 .

Unemployment, at 1 percent, has reached its historical low. These pressures in goods and labor markets drove inflation outside the central bank's tolerance range. CPI inflation peaked at over 8 percent in 2006 and the recent decline primarily reflects reductions in VAT and excise taxes that took effect in March. Demand pressures have also been felt in asset markets, with equity prices quadrupling over the last three years and real house prices doubling over the past four years. The boom has been funded externally, with the current account deficit reaching 27 percent of GDP in 2006, reflecting large deficits on both the income and trade balances. Net external debt now stands in excess of 200 percent of GDP and household debt is close to 250 percent of disposable income.

Figure 2. Indicators of Macro Imbalance

Tight goods and...

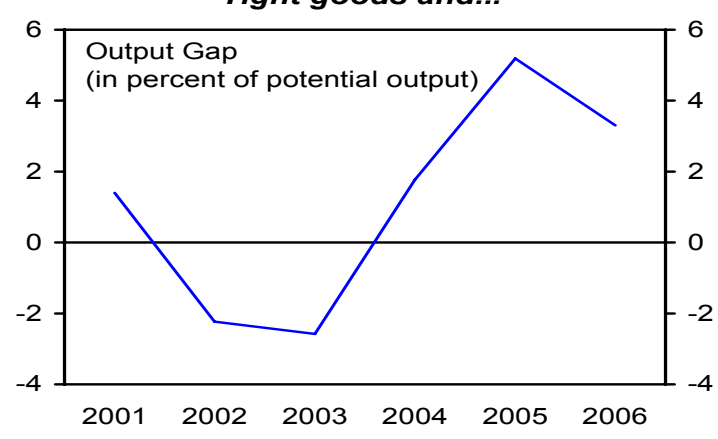

...drove inflation well outside

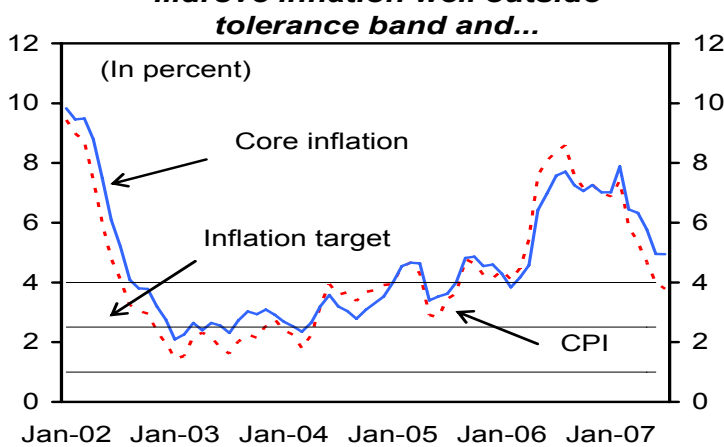

Jan-02 Jan-03 Jan-04 Jan-05 Jan-06 Jan-07

Borrowing drove current account deficit and

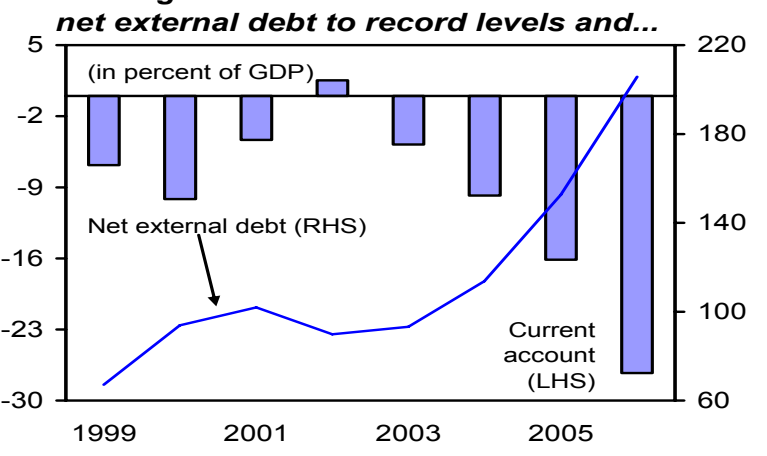

...labor markets...
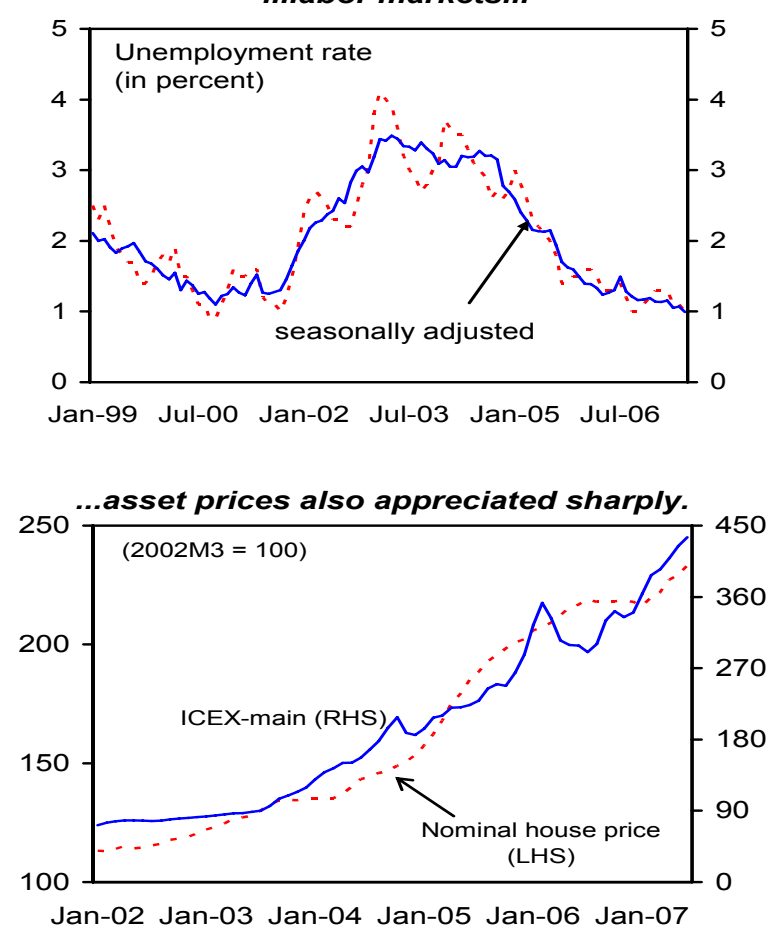

Jan-02 Jan-03 Jan-04 Jan-05 Jan-06 Jan-07

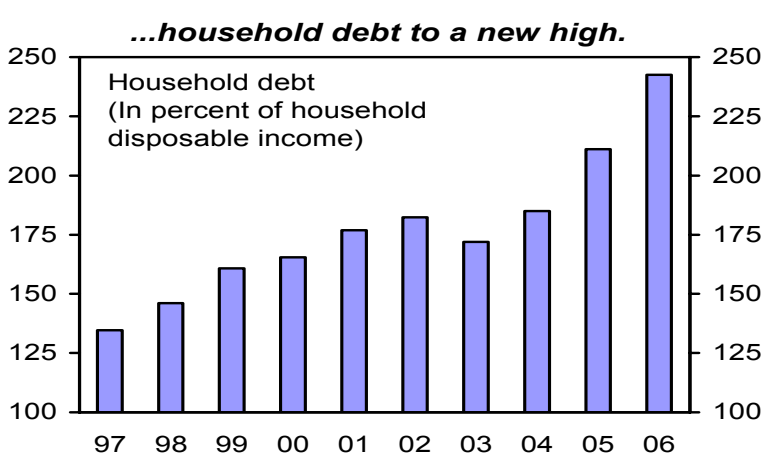




\section{Monetary policy tightened throughout the upswing and the inflation-targeting} framework evolved. Since its trough of 5.3 percent in May 2004, the annualized policy rate has been steadily increased to $14 \frac{1}{4}$ percent. In addition, the central bank has been improving communications to help anchor inflation expectations. In the fall of 2005, it began announcing a schedule for policy meetings that conclude with a public statement outlining the decision. Shortly after, it began publishing the central bank staff's view of the interest rate path required to return inflation to target. This now constitutes the baseline forecast in the Monetary Bulletin, the central bank's key policy communications publication. In the March Monetary Bulletin, the central bank's forecast indicated that to return inflation to target, the policy rate would stay at $14 \frac{1}{4}$ percent until end-2007, and could ease gradually thereafter.

\section{Despite the policy initiatives, the effectiveness of monetary policy was}

undermined by several factors. First, easing in lending criteria and changes to funding strategies at the publicly owned Housing Financing Fund (HFF) sparked a competitive battle with the private banks. ${ }^{1}$ For a sustained period while the policy rate rose, real mortgage rates declined. Further, banks introduced mortgage products that newly allowed households to borrow against their housing equity. Throughout the period, credit criteria at the HFF and banks continued to loosen. Consequently, household credit expanded and private consumption growth accelerated. Second, the rising policy rate led to an appreciating króna and falling import prices, further fuelling private The Credit Easing Reforms at the Housing Financing Fund

\begin{tabular}{|c|c|}
\hline Date & Reform \\
\hline January 2004 & $\begin{array}{l}\text { New house loan ceiling increased to } 9.7 \text { million krona from } 9 \text { million } \\
\text { Used house loan ceiling increased to } 9.2 \text { million krona from } 8 \text { million }\end{array}$ \\
\hline Summer 2004 & Funding change lowers real mortgage rates by almost 1 percentage point \\
\hline October 2004 & $\begin{array}{l}\text { New and used housing loan ceilings increased to } 11.5 \text { million krona } \\
\text { LTV ratio increased to } 100 \text { percent of fire replacement value from } 85 \text { percent }\end{array}$ \\
\hline December 2004 & $\begin{array}{l}\text { New and used housing loan ceilings increased to } 14.9 \text { million krona } \\
\text { General LTV ratio (including land) increased to } 90 \text { percent }\end{array}$ \\
\hline April 2006 & New and used housing loan ceilings increased to 18 million krona \\
\hline July 2006 & $\begin{array}{l}\text { General LTV ratio temporarily reduced to } 80 \text { percent } \\
\text { Loan ceiling temporarily reduced to } 17 \text { million krona }\end{array}$ \\
\hline March 2007 & $\begin{array}{l}\text { General LTV ratio returned to } 90 \text { percent } \\
\text { Loan ceiling returned to } 18 \text { million krona }\end{array}$ \\
\hline
\end{tabular}
consumption demand.

Third, low international interest rates and abundant liquidity enabled Icelandic firms to borrow in foreign currency at low rates. Finally, the krona (ISK) Eurobond carry trade enabled banks access to ample funding at relatively attractive rates to finance domestic credit expansion.

\footnotetext{
${ }^{1}$ For analysis of Iceland's mortgage market see IMF Country Report No. 05/366.
} 
Figure 3. Limited Effectiveness of Monetary Policy
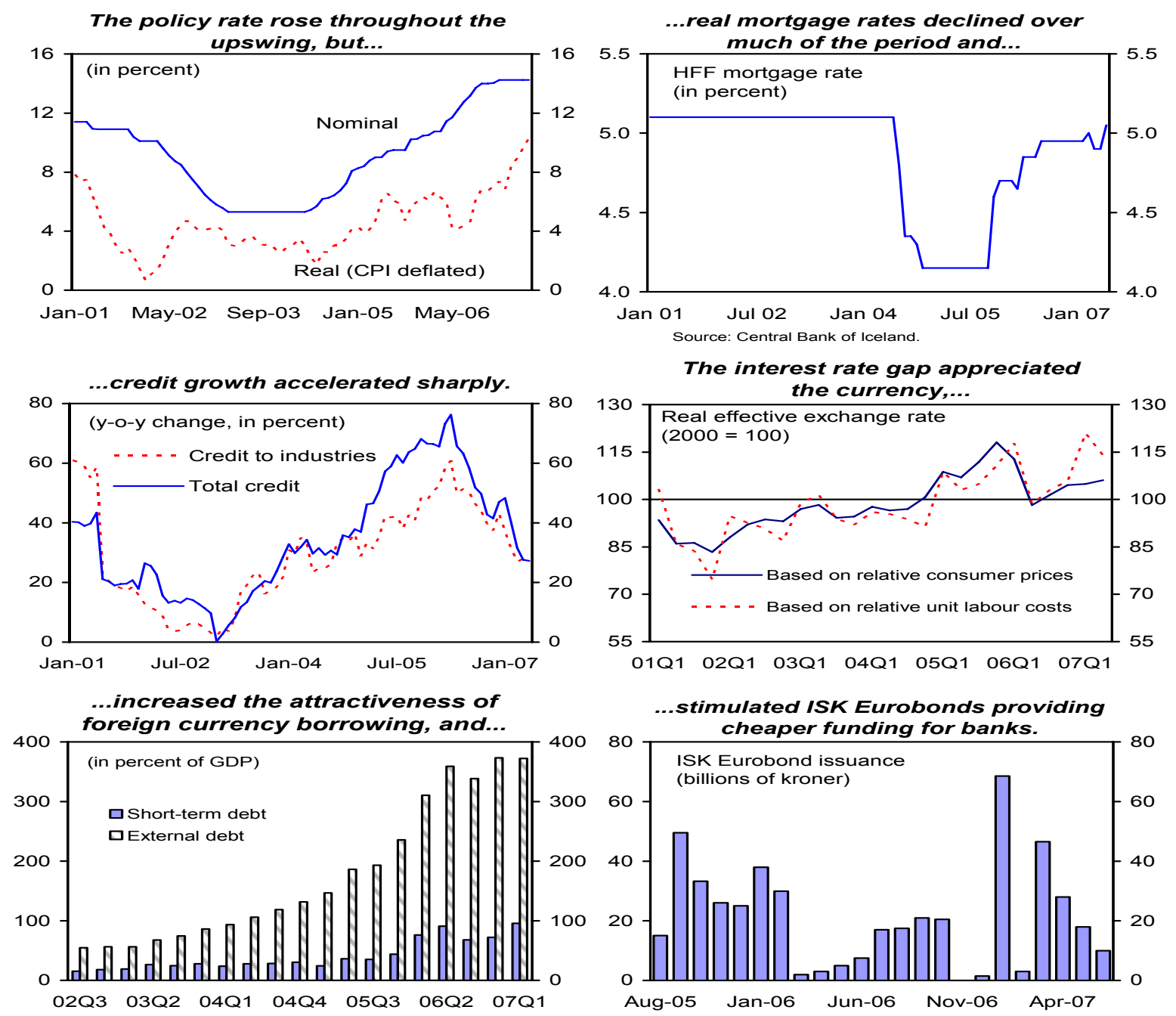

\section{Banks remain profitable and well capitalized, but risks remain. Banks posted} record profits in 2006 as diversification across businesses and countries mitigated pressures on margins at home. Almost half of the banks' 2006 income was generated outside Iceland. Household and corporate customers are heavily indebted, but credit quality appears high with a non-performing-loan ratio of roughly 0.5 percent. Further, household disposable income growth has been strong and most corporates borrowing in foreign currency are naturally hedged. Liquidity risk has been reduced, with 2007 maturing debt already pre-funded, and sources and instruments diversified. Cross and related-parties holdings of equity have been sold down, increasing ownership transparency and reducing the risks associated with connected lending. At end-2006, banks had Tier 1 capital ratios in excess of 10 percent and financial supervisor (FME) stress tests suggested that the banking groups had sufficient capital to withstand a combination of extreme credit and market shocks. However, the rapid pace of credit growth suggests that credit quality could become a concern in the event of a sharp domestic downturn and the banks' high reliance on international capital markets for funding could leave them vulnerable to market shocks. 
Figure 4. The Banking Sector
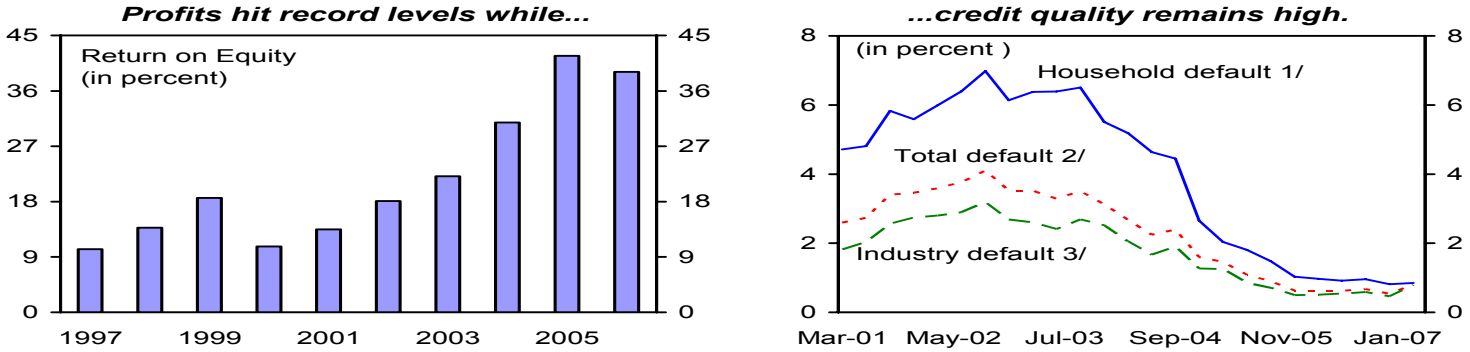

Short-term proportion of external debt
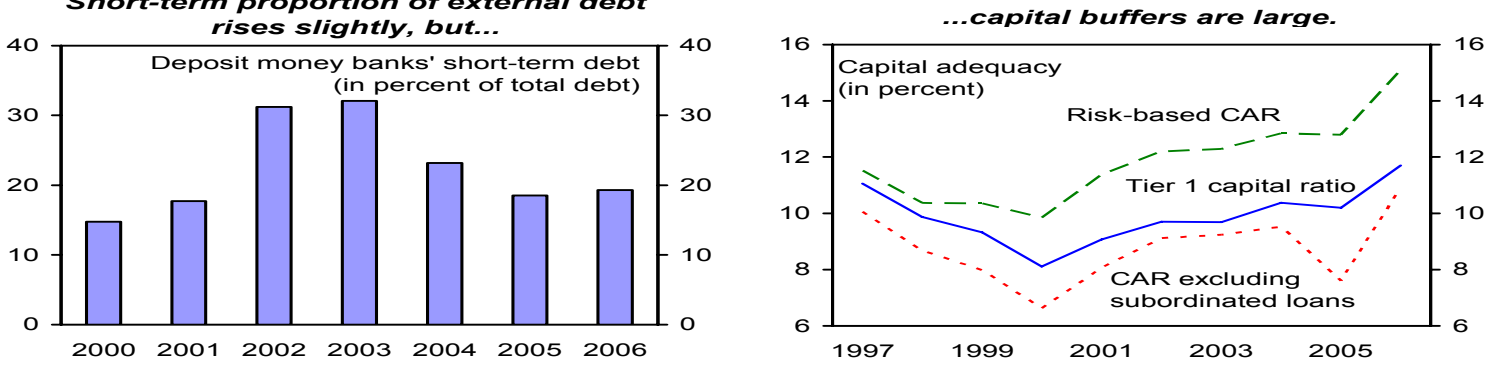

Sources: Bloomberg, Central Bank of Iceland, FME, and Statistics Iceland.

1/ As a percent of loans to households.

\section{The record current account deficit of $\mathbf{2 0 0 6}$ and credit downgrades this year}

caused little disruption. Unlike during a similar period last year, the króna has remained

strong and confidence in the Icelandic banks stayed high as indicated by their equity prices and credit default swap spreads. In addition to reflecting the banks' improved risk profile, this may also be due to a greater understanding in international capital markets of Iceland's unique circumstances. The banks have done a better job of explaining their business model and emphasizing that the size of the domestic economy can distort the picture suggested by standard ratios to GDP.

\begin{tabular}{|c|c|c|c|}
\hline \multicolumn{4}{|c|}{ Fitch } \\
\hline & Long-Term & Short-Term & Outlook \\
\hline \multicolumn{4}{|l|}{ Iceland } \\
\hline Mar. 15, 2007 & $A+$ & F1 & Stable \\
\hline Nov. 9, 2006 & AA- & $\mathrm{F} 1+$ & Negative \\
\hline Feb. 21, 2006 & AA- & $\mathrm{F} 1+$ & Negative \\
\hline Mar. 31, 2003 & AA- & $\mathrm{F} 1+$ & Stable \\
\hline \multicolumn{4}{|l|}{ Kaupthing } \\
\hline Mar. 15, 2007 & A & F1 & Stable \\
\hline Aug. 30,2006 & A & F1 & Stable \\
\hline Feb. 23,2006 & A & $\mathrm{F} 1$ & Stable \\
\hline Nov. 22, 2005 & A & F1 & Stable \\
\hline \multicolumn{4}{|l|}{ Glitnir } \\
\hline Mar. 15, 2007 & A & F1 & Stable \\
\hline Aug. 30,2006 & A & F1 & Stable \\
\hline Feb. 23,2006 & A & F1 & Stable \\
\hline Nov. 22,2005 & A & F1 & Stable \\
\hline \multicolumn{4}{|l|}{ Landsbanki } \\
\hline Mar. 15, 2007 & A & F1 & Stable \\
\hline Nov. 28,2006 & A & F1 & Stable \\
\hline Feb. 23, 2006 & A & F1 & Stable \\
\hline Nov. 29, 2005 & A & F1 & Stable \\
\hline
\end{tabular}

Figure 5. Market Indicators
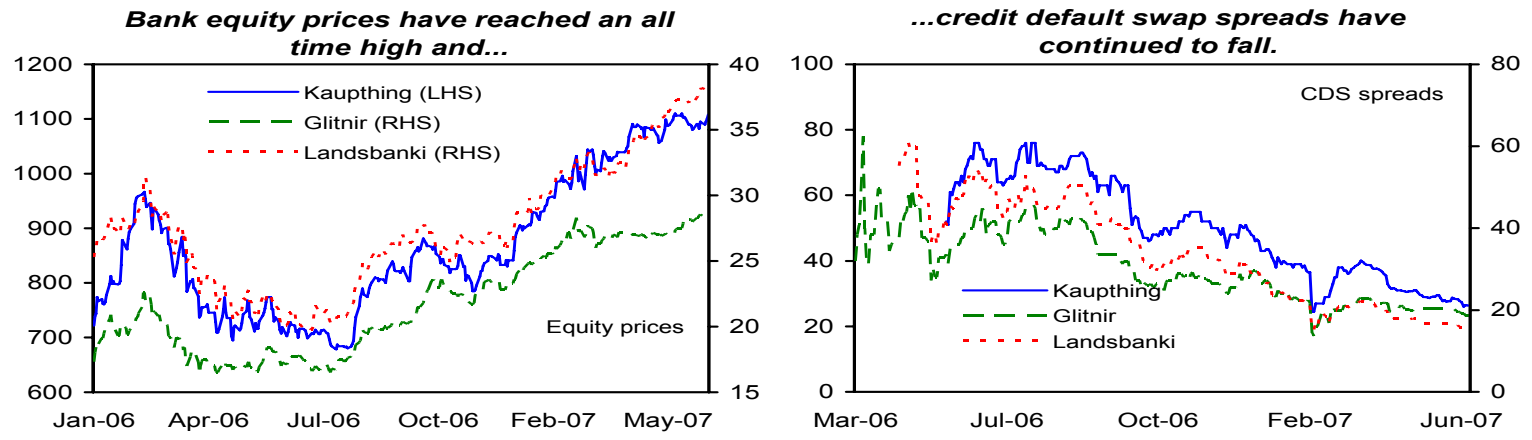
7. Although the fiscal balance improved during the upswing, a large portion of the improvement was cyclical, and the policy stance eased in 2007. The fiscal balance swung from a deficit of almost 3 percent of GDP in 2003 to a surplus of just over 5 percent of GDP in 2006; the underlying (structural) adjustment was, however, more contained. Standard cyclical adjustment techniques cut these surpluses by more than $1 / 3$ and the tendency of revenue elasticities to move in a procyclical fashion suggests that an even larger adjustment is appropriate. ${ }^{2}$ Given the limited effectiveness of monetary policy, the actual fiscal restraint failed to reduced demand pressures and imbalances. The 2007 budget implies a 2 percentage point easing in

General Government Structural Adjustment, 2007

\begin{tabular}{lr} 
Change in structural balance & -1.3 \\
& \\
of which: & -0.3 \\
Income tax reductions & -1.0 \\
VAT and excise tax reduction & -0.5 \\
Expenditure slippage & 0.5 \\
Other & \\
\hline
\end{tabular}
the surplus-to-GDP ratio, reflecting primarily cuts in income, VAT, and excise taxes implemented in 2007 Q1. Delaying the fiscal easing until after domestic macroeconomic balance had been restored would have been prudent.

Figure 6. Fiscal Balance
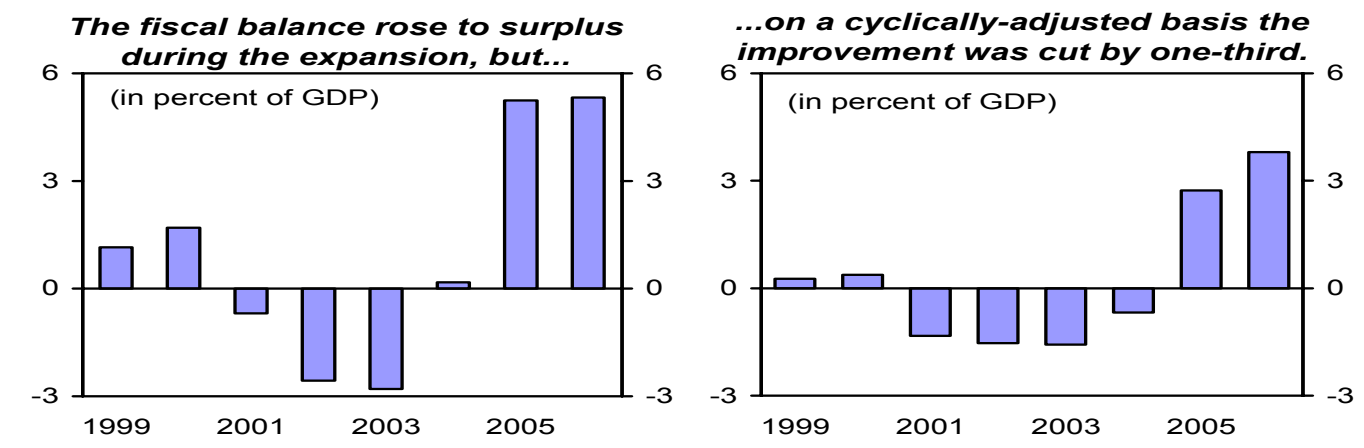

Implementation of Fund Advice

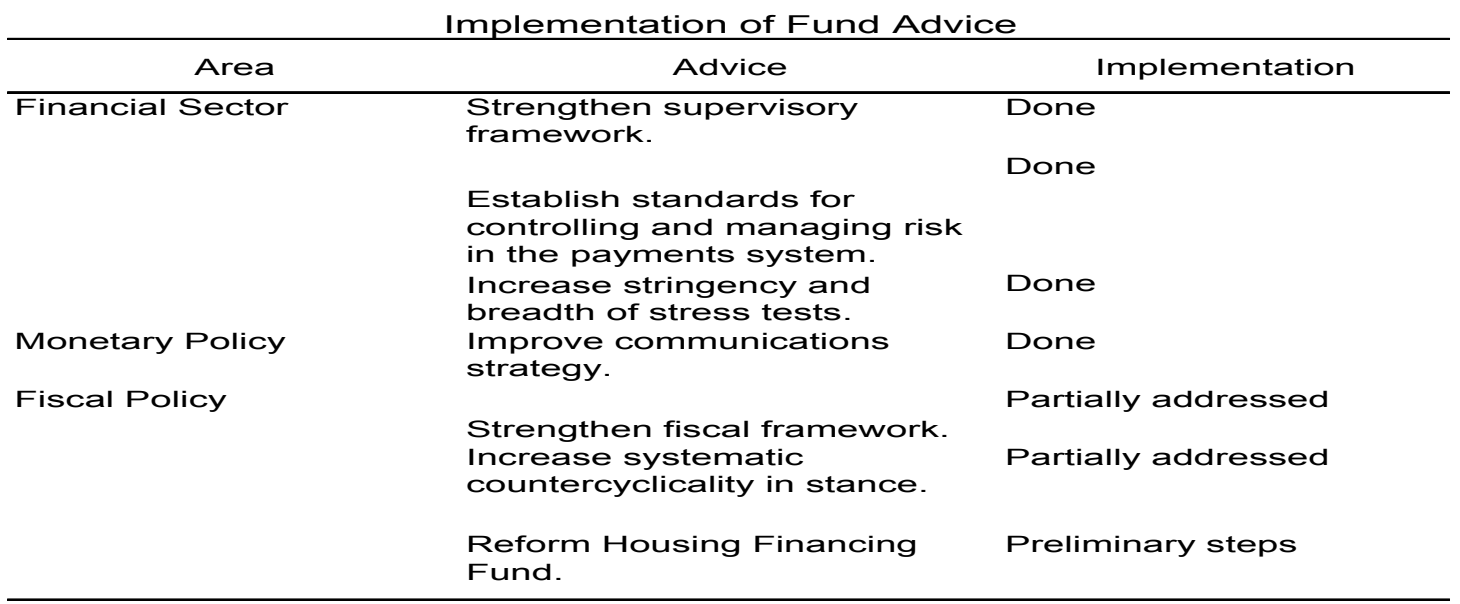

\footnotetext{
${ }^{2}$ See selected issues chapter 2 "Toward a Robust Fiscal Framework for Iceland: Motivation and Practical Suggestions."
} 


\section{Policy Discussions}

8. With signals of slowing mixed and large imbalances, discussions focused on the policies needed to ensure that the needed retrenchment occurs smoothly, restoring balance with minimal disruption. Following previous overheating periods, domestic demand in Iceland adjusted quickly, restoring balance without long-lived negative macroeconomic implications. However, the risk of continued strength in private consumption illustrates that policymakers must ensure that polices are providing appropriate incentives to achieve this outcome. Further, given the current, and likely growing, pressures that globalization places on macroeconomic stabilization in small open economies, the design and implementation of stability-oriented policy frameworks need to continually evolve. ${ }^{3}$ Accordingly discussions focused on:

- Monetary policy: the path for policy interest rates that will guard against high inflation becoming entrenched and measures to improve the effectiveness of the policy instrument;

- Financial sector: the authorities' role in ensuring that banks continue to improve their risk profiles, that credit quality remains high, and that developments at financial companies do not limit the effectiveness of domestic stabilization policy;

- $\quad$ Fiscal policy: the prospects for achieving a tighter fiscal stance until it is clear that demand pressures have eased sufficiently; and

- $\quad$ Fiscal framework: the development and implementation of a more rules-based framework that will achieve greater monetary and fiscal policy coordination, thereby reducing economic volatility.

\section{A. Outlook and Risks}

9. There were important differences in views on the current momentum in the economy and core inflation pressures. There was agreement that inflation would return to target and the current account deficit would decline substantially over the forecast horizon, however, there were differences in timing. Both staff and the central bank saw more momentum in the economy than the fiscal authority, which saw growth moderating close to zero in 2007 and then rebounding back close to potential. Different views on the level of potential output underlie these outlooks with the fiscal authorities' estimate higher. In all outlooks, the completion of the aluminum-sector projects underlies the projected decline in investment. Different views on the sustainable level of private consumption largely account

\footnotetext{
${ }^{3}$ The Fund and the central bank jointly hosted a pre-mission conference summarized in selected issues chapter 4, "Conference Summary: The Challenges of Globalization for Small Open Economies with Independent Currencies."
} 
for the dissimilar GDP profiles. Staff expect consumption to slow but remain above a sustainable level in 2007, buoyed by tax cuts, currency strength, income growth, and continued asset price appreciation. However, increasing real interest rates coupled with record high household debt and rising import prices are expected to encourage households to rein in expenditure in 2008. Staff and the central bank estimate that the output gap will remain positive in 2007, before moving into excess supply in late-2008. The fiscal authorities, however, estimate that the output gap turns negative in 2007 and inflation returns to the target sooner. Views on the evolution of the current account were broadly similar, with staff expecting it to fall by roughly half in 2007 and to under 10 percent of GDP in 2008.

\section{Staff and the central bank viewed the balance of risks to lie on the upside. The} rebound in consumer confidence in early 2007 warns that the retrenchment in private consumption could be delayed. ${ }^{4}$ Expectations could be supported by new investment projects drawing closer. ${ }^{5}$ Further, the impact of increases in the policy interest rate on household debtservice cost has been muted by competition between the banks and the HFF. In the absence of HFF reform, it was agreed that monetary policy is likely to have only a limited impact on households. Should consumption not ease as forecast, demand pressures will keep inflation and interest rates high, delaying re-equilibration in the exchange rate from its currently overvalued level.

\section{B. Fiscal Policy}

\section{Notwithstanding the risks, the fiscal authorities saw less need and little scope for} tightening the fiscal stance. Although the tax cut portion of the 2007 easing had already been implemented, staff enquired about the scope for delaying some public investment projects and constraining the growth in public consumption over the remainder of 2007 and in 2008. Staff noted that should the economy weaken faster than expected, automatic stabilizers would ensure that

General Government: Options for Measures in 2007 and 2008 (in percent of GDP)

\begin{tabular}{lrrr}
\hline & 2006 & 2007 & 2008 \\
\hline Structural balance before proposed measures & 3.8 & 2.5 & -0.2 \\
$\quad$ Reduce expenditure by 3 percent from budgeted level & $\ldots$ & 1.3 & 2.2 \\
$\quad$ in 2007 and 4 1/2 percent in 2008 & & & \\
Structural balance after proposed measures & 3.8 & 3.8 & 2.0 \\
Memorandum items: & & & \\
Nominal expenditure growth (before measures) & & & \\
Nominal expenditure growth (after measures) & 9.3 & 11.8 & 11.0 \\
\hline
\end{tabular}
the fiscal stance eased appropriately. The authorities viewed there to be less need for

\footnotetext{
${ }^{4}$ In early July, the government reduced the cod quota which will reduce GDP in 2008 by 1 percent. While this will only have a small impact on unemployment and the output gap, it could dampen consumer confidence.

${ }^{5}$ The Helguvik project will likely begin in 2008, with total investment of roughly 10 percent of 2006 GDP spaced out over 3 years. Additional projects remain under consideration.
} 
additional fiscal restraint given their outlook, and limited scope, particularly in light of the tightness in labor markets.

\section{The authorities saw merit in strengthening the medium-term fiscal framework.}

To help reduce macroeconomic volatility, staff recommend a package of measures to strengthen the fiscal framework (Box 1). Strengthening the expenditure rules and extending them to local governments was seen as feasible, as was using parliamentary committees to increase parliament's ownership of the ceilings. While agreeing that nominal spending ceilings would improve the countercyclical impulse from fiscal policy, practical difficulties were noted given high inflation uncertainty. The authorities also noted that it was not immediately obvious where an independent forecast to underpin the budget could be generated.

\section{Box 1: Options for Reforming the Fiscal Framework ${ }^{1}$}

A more rules-based fiscal framework would improve macroeconomic stabilization and Iceland could look to the reform experiences of countries like Belgium and the Netherlands where coalition governments are also the norm. Options include:

- $\quad$ Couch expenditure rules in terms of rolling multi-year expenditure ceilings that are binding on ministries and local governments. Stop adding expenditure at the legislative stage and end the use of supplementaries.

- $\quad$ Switch from real to nominal expenditure ceilings based on the inflation target.

- Use stakeholder committees to coordinate fiscal policy targets. Strengthen parliamentary committees to take greater ownership of ceilings.

- $\quad$ Specify detailed expenditure ceilings for the life of the government as part of the coalition agreement.

- $\quad$ Underpin the budget with independent macroeconomic forecasts.

${ }^{1}$ Selected issues chapter 2: "Toward a Robust Fiscal Framework for Iceland: Motivation and Practical Suggestions." 


\section{Monetary Policy}

13. There was agreement that core inflation pressures remained strong. Although temporary factors were lowering headline inflation, continued tightness in goods and labor markets, and the pickup in house price inflation signaled greater core inflation pressures than expected at the time of the March Monetary Bulletin. It was noted that although immigration from eastern Europe had eased labor market constraints in construction and services, shortages of highly skilled workers were generating wage pressures in other sectors. While seeing the need for further tightening, the authorities noted that increased capital flows could lead to perverse short-term effects. Ample credit would be available to households and a further strengthening in the exchange rate could boost consumer confidence. In addition, delaying the re-equilibration in the exchange rate, which the authorities agreed was overvalued by 15 to 25 percent due primarily to the impact of high domestic interest rates (Box 2), could slow needed current account adjustment. ${ }^{6}$

Figure 7. Components of CPI Inflation

(Contributions to CPI Inflation over the past 12 months)

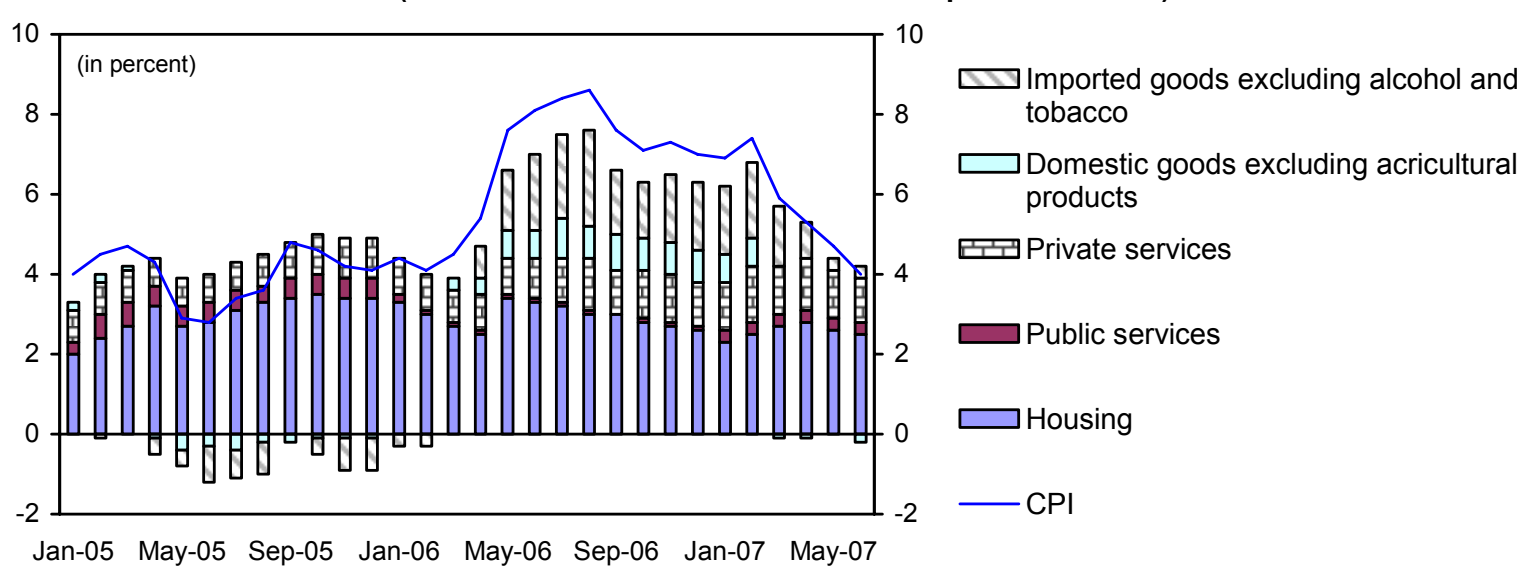

\footnotetext{
${ }^{6}$ Following the mission, the July Monetary Bulletin indicated that that the policy rate would need to be held at its current rate for longer than indicated in the March Monetary Bulletin owing to increased inflationary pressures. Subsequently, the HFF and banks raised mortgage rates.
} 


\section{Box 2. The Equilibrium Real Exchange Rate ${ }^{1}$}

The magnitude of external imbalances raises questions about Iceland's external sustainability (Appendix I) and the extent of disequilibrium in the exchange rate. Calculations done for the 2006 Article IV consultations suggested REER overvaluation of 10-15 percent.

Since then, the currency has appreciated, the current account deficit has widened, and external debt has grown. The three methodologies used in the CGER exercise ${ }^{2}$ suggest that, currently, REER adjustment needed to bring it in line with fundamentals is in the range of $15-25$ percent.
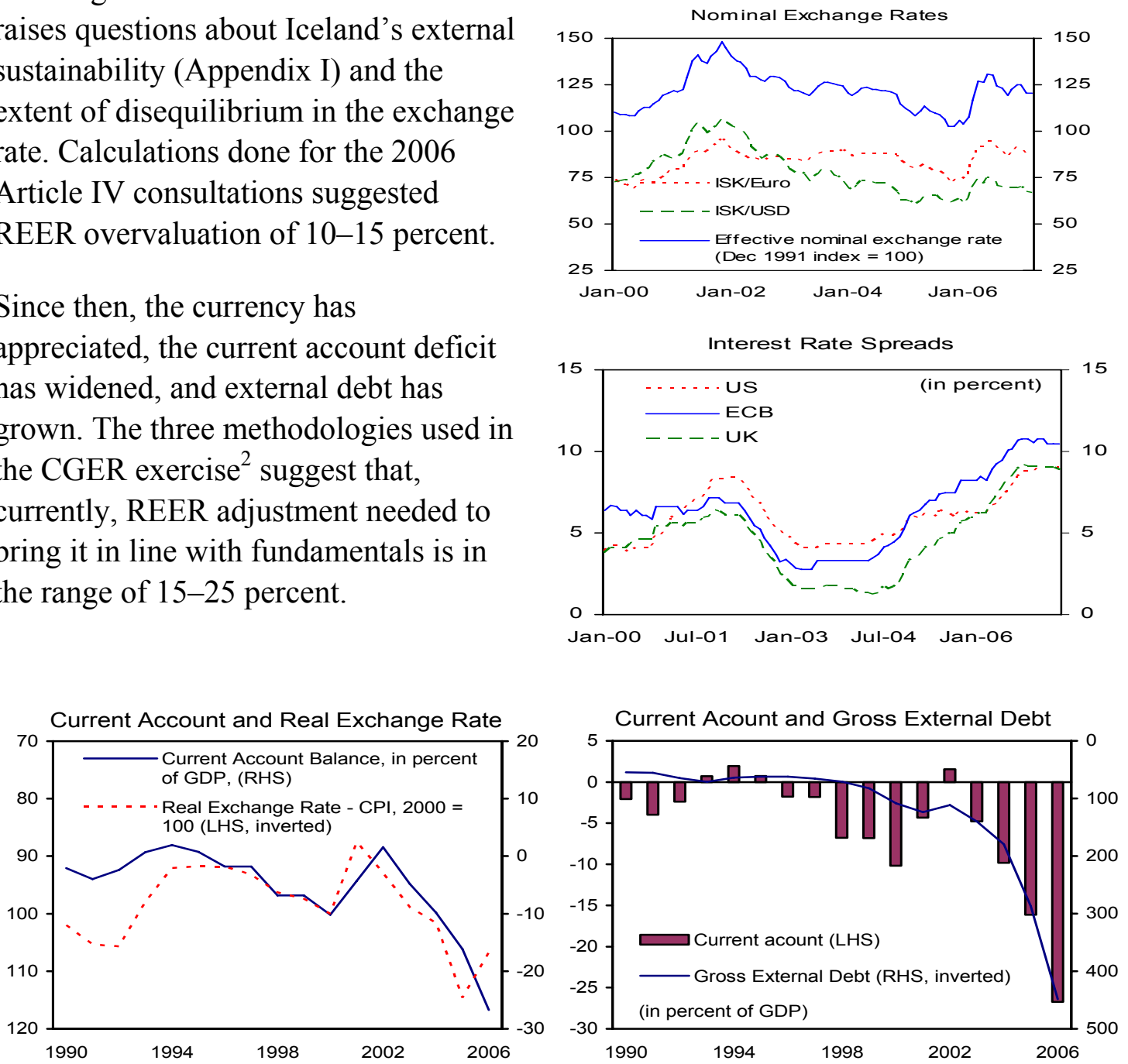

${ }^{1}$ Selected issues chapter 1 "Estimating Iceland's Real Equilibrium Exchange Rate."

2 "Methodology for CGER Exchange Rate Assessments," IMF Research Department, available at http://www.imf.org/external/pp/longres.aspx?id=3957.

14. The authorities viewed the publication of the path for interest rates required to return inflation to target as successful. In the March Monetary Bulletin, the central forecast was based on the interest rate path that the central bank staff viewed necessary to return inflation to target. It was noted that virtually all market reaction had been positive. Forward market rates and banks' interest rate forecasts had moved closer to the central bank's view, which had not been the case when this scenario was only included as an alternative. 


\section{There was unanimous agreement that the competition between the banks and} the HFF was limiting the impact of monetary policy. The HFF funds its mortgage lending through issues of government-guaranteed long-term indexed bonds. Consequently, its real mortgage rates only rose as global interest rates rose. The banks fund their ISK mortgage lending with shorter-term borrowing, the cost of which is affected by the central bank's policy instrument. To maintain their share of the mortgage market, banks match HFF rates and appear to be lending at rates below their cost of funds. This prevents the policy rate from affecting household debt-service costs and has encouraged banks to increase their foreigncurrency mortgage lending, which can be done more profitably with households bearing the currency risk. While the authorities agreed that HFF reform would increase the effectiveness of monetary policy, they indicated that it could take a number of years to implement, in part because of concerns over ensuring access to adequate mortgage finance throughout the country. ${ }^{7}$

\section{Financial Stability}

\section{Banks responded effectively to the supervisor's and investors' concerns in early} 2006, though challenges remain. Despite Iceland's large current account deficit in 2006 and credit downgrade early in 2007, the banks' resilience to the market turbulence in March of this year was cited as evidence of their effective response. The FME noted that because of Icelandic banks' high dependence on capital markets for funding, they would always be more vulnerable to capital market sentiment, and consequently, liquidity management would always need close monitoring. Banks noted that they have sufficient liquid assets to meet their business obligations for 12 to 18 months without needing market access. In addition, banks' diversification of funding sources suggests that they would continue to have market access, albeit it at a higher cost of funds, should the ISK Eurobond flows cease (Box 3). At the same time, it was noted that there is growing importance on banks' ability to effectively manage new and more complex risks. It was also noted that the rapid foreign expansion of the banks had increased awareness of the importance of improved cross-border collaboration, crisis management planning, and adequate supervisory resources; and progress was being made on all fronts. For example, Iceland will participate in a Nordic financial system contingency exercise in September.

\footnotetext{
${ }^{7}$ In IMF Country Report No. 05/366, along with the analysis of the Icelandic mortgage market, staff outlined a set of guiding principles for reform of the HFF to significantly shrink its role in the retail mortgage market. These principles were to ensure that the positive aspects of the current system would be retained while allowing it to evolve in a manner that would strengthen both the transmission of monetary policy and the stability of the financial sector. On July 2, 2007 following the mission, the Ministry of Social Affairs reduced the maximum LTV ratio of the HFF to 80 percent and announced that the HFF would shift its lending focus more toward its social objectives. Commentators see this as the first step in needed HFF reform.
} 


\section{Box 3: Króna-Denominated Eurobond Issues ${ }^{1}$}

ISK Eurobond issuance began in

August 2005. The strength of the market reflects high domestic interest rates, a strong króna, search for yield, and buoyant domestic credit demand. After dropping off in early-2006, issuance picked up late in the year.

ISK Eurobond transactions are founded on comparative advantage. Highly-rated

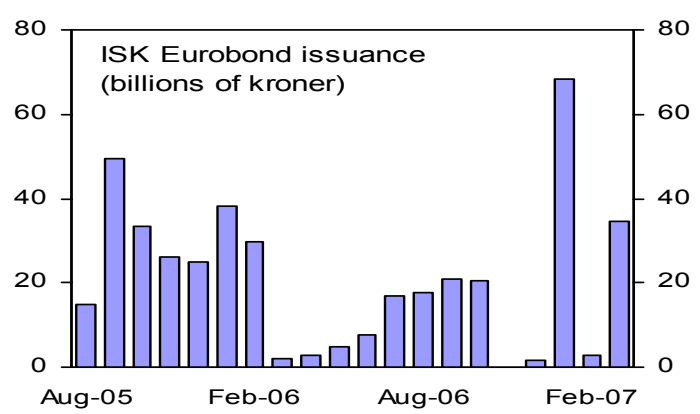
international institutions can issue króna-denominated bonds to carry-trade investors at lower interest rates than can Icelandic banks, but still higher than in most international markets. They then offer the króna to the local banks. In return, local banks borrow foreign currency abroad to swap with the issuer. The swap interest rate lies between the Eurobond rate and the rate Icelandic banks would have had to pay.

The sustainability of this activity depends on the attractiveness of króna yields, and investor interest in Icelandic assets. Market participants note that Iceland is largely seen as an opportunistic investment rather than a "must hold", and could be more vulnerable to a sell-off.

${ }^{1}$ Seleted issues chapter 3 "Iceland: Financial Sector Developments and Risks to the Outlook."

\section{Although stress tests suggest that banks have adequate capital to withstand large} shocks, there was agreement that continued development of stress testing techniques would be important. The stress tests performed by the FME incorporate shocks that are quite large and the bank-by-bank impact on capital adequacy is published quarterly on the FME's website. ${ }^{8}$ When discussing whether the magnitudes of the shocks were appropriate, the FME noted that while imbalances in Iceland have grown, the shocks are always performed relative to the latest data outturns. Consequently, once markets start to move, the tests track the evolution of capital adequacy quarterly, providing ample lead time to introduce measures to restore capital buffers if necessary. However, there was agreement that current methodologies have a weakness as they ignore second-round effects, but this applies to virtually all stress tests.

\section{Focus has shifted from short-term issues on the banks' liabilities side to} medium-term issues of credit quality. Despite low default rates, the rapid pace of credit growth and the extent of household and firm leverage means credit quality could become an issue. The majority of household debt, however, is long-term and so interest rate risk is low. Although the bulk of banks' foreign currency lending is to firms with natural hedges, the increase in foreign currency lending to the generally unhedged retail, construction, and

\footnotetext{
${ }^{8}$ See http://www.fme.is/?PageID=168.
} 
19. household sectors poses a growing concern. The magnitude of these exposures remains small, but the growth should be monitored closely because there are indications that many are underestimating the potential rise in the cost of servicing these loans, expecting the currency to remain strong, even in the medium term. ${ }^{9}$

20. The prospect of financial companies reporting their accounts in foreign currency has raised concerns. Icelandic financial companies are allowed to keep books and draw up accounts in their functional currency, which could be foreign. ${ }^{10}$ While one concern is technical, the key concern is the potential impact on ISK denominated markets. Currently, the three large banks are the ISK market makers. If they were to shift their accounting into another currency, they might discontinue their ISK market activity, with potentially significant implications for liquidity and the transmission of monetary policy.

\section{E. External Sustainability}

21. The current account is expected to improve sharply, notably slowing the rate of growth in net external indebtedness. The deficit on the trade balance should improve significantly in 2007 , reflecting increasing exports as aluminum capacity comes on stream and declining imports due to the completion of the investment projects and moderation in consumption (the 2007 Q1 current account deficit improved to 9.7 percent of GDP). The trade balance is forecast to improve further in 2008 and beyond as imports decline with private consumption returning a sustainable level. The income balance is also forecast to improve markedly, as the larger proportion of higher income earning FDI and equities in Iceland foreign assets yields a positive net return.

\section{Although the level of Iceland's external indebtedness raises concern regarding} sustainability, discussions highlighted several mitigating factors. Debt sustainability analysis presented in Appendix I illustrates how different macroeconomic shocks could increase Iceland's net external debt above the staff's medium-term baseline, possibly leading to servicing difficulties. In particular, krona depreciation increases the level of net external debt notably. These scenarios illustrate that in the event of adverse developments, behavior will need to adjust to ensure stability. Encouragingly, Iceland's debt servicing capacity has grown substantially with the increased capacity in the aluminum sector and households are wealthy with favorable income prospects. Further, because of the scale and different composition of Iceland's foreign assets and liabilities, the net international investment position (IIP), which shows a considerable stronger net position because it includes direct investment and equity, exhibits significantly less deterioration under the depreciation scenario. In addition, as detailed in Appendix I, international accounting standards for

\footnotetext{
${ }^{9}$ The FME expects risks associated with unhedged FX loans to be incorporated under Pillar II in Basel II.

${ }^{10}$ See selected issues chapter 3, "Iceland: Financial Sector Developments and Risks to the Outlook."
} 
valuing different classes of assets imply that even the net IIP may overstate Iceland's true level of external indebtedness.

\section{Staff ApPraisal}

23. Iceland's medium-term prospects remain enviable. Open and flexible markets, sound institutions, and skillful management of natural endowments have enabled Iceland to benefit from the opportunities afforded by globalization. However, the growing openness of international markets can also reduce macroeconomic stability, and the road ahead poses challenges that policymakers must address to ensure a smooth ride.

24. Greater macroeconomic stability is needed. In part, the forces of globalization can be seen in Iceland's large current account deficits, increasing indebtedness, and persistently high consumer price inflation, which all reflect the unsustainable pace of domestic demand growth over the last several years. In the near term, policies will need to tighten to ensure that domestic demand is reduced, thereby moderating both internal and external imbalances. Additionally, steps need to be taken to strengthen the ability of both monetary and fiscal policy to moderate macroeconomic volatility.

25. Fiscal policy needs to be tighter than budgeted. The tax cuts in early-2007 eased the fiscal stance prematurely. Measures should be introduced to ensure that domestic demand pressures moderate sufficiently without relying too heavily on monetary policy. First, the planned increase in public investment should be slowed. Second, new spending initiatives should not be introduced until demand pressures have fully abated. Third, in the upcoming wage negotiations, public sector wage growth needs to be restrained despite labor-market tightness, and consideration should be given to facilitating the import of skilled labor from non-EU countries.

\section{To increase fiscal policy's contribution to macroeconomic stabilization, the} medium-term fiscal framework should be strengthened. Mechanisms need to be introduced to ensure that general government spending targets are achieved in each and every year. Explicit agreements between the central and local governments would help achieve this goal. Further, moving to a framework with nominal spending targets based on the central bank's target rate of inflation would lead to a systematically strong countercyclical fiscal stance.

27. Monetary policy needs to tighten to ease demand pressures and anchor inflation expectations. Despite the fall in headline inflation resulting from the reduction in value added and excise taxes, core inflation pressures are stronger than expected at the time of the March Monetary Bulletin. Looking further down the road, with currency overvaluation in the 15-25 percent range owing to high short-term interest rates, the currency will at some stage depreciate to a more sustainable level as inflation is returned to target. When this occurs, monetary policy must guard against second-round inflation effects. 
28. Reform of the publicly-owned HFF is crucial. This is necessary to increase the effectiveness of monetary policy and reduce the threat to stability from potentially volatile international capital flows. Competition between the HFF and domestic banks is preventing the central bank's policy instrument from effectively reducing domestic demand pressures and results in short-term interest rates that are much higher than otherwise. Those sectors of the economy not able to shield themselves from high interest rates may be permanently damaged. High short-term interest rates are also increasing Iceland's attractiveness to the carry trade, appreciating the currency, and increasing external imbalances. As a first step, HFF lending limits and loan-to-value ratios should be reduced. Subsequently, the government needs to permanently remove the distortion in the domestic financial market arising from the presence of the publicly-owned HFF and introduce specifically targeted programs to ensure access to mortgage funding in all areas of the country.

\section{The financial system withstood the market stress in early-2006 admirably, but} new risks may be emerging. Banks took important steps over the past year to reduce vulnerabilities and increase resilience. As banks continue to expand rapidly and the complexity of their operations increases, risk management practices must develop commensurately and credit risk should be a key focus for banks and supervisors. Lending growth remains very strong, and while the delinquency rate is low, it is a lagging indicator. Lending standards and the quality of loan collateral need to be monitored closely. Further, banks' foreign-currency lending to households, which has increased sharply, could potentially become an important indirect credit risk as unhedged households may underestimate the impact of currency movements on their debt-service costs. Reform of the HFF would also improve the pricing of risk in the lending market.

30. Stress tests conducted by the FME suggest that banks have adequate capital to withstand extreme credit and market shocks. However, these scenarios do not account for the second-round effects of such shocks and therefore improvements in stress-testing techniques should continue. Given the rapid expansion of the financial sector, the envisaged further strengthening of the FME's resources is welcome. At the same time, the authorities' emphasis on cross-border collaboration in supervision and crisis management is encouraging.

31. The next Article IV consultation is recommended to occur on the 12-month cycle. 
Table 1. Iceland: Selected Economic Indicators, 2000-08

\begin{tabular}{|c|c|c|c|c|c|c|c|c|c|}
\hline & 2000 & 2001 & 2002 & 2003 & 2004 & 2005 & $\begin{array}{c}2006 \\
\text { prelim. }\end{array}$ & $\begin{array}{c}2007 \\
\text { staff proj. }\end{array}$ & $\begin{array}{c}2008 \\
\text { staff proj }\end{array}$ \\
\hline \multicolumn{10}{|c|}{ (Percentage change unless otherwise noted) } \\
\hline \multicolumn{10}{|l|}{ National Accounts (constant prices) } \\
\hline Gross domestic product & 4.3 & 3.9 & -0.1 & 2.7 & 7.6 & 7.2 & 2.6 & 2.1 & -0.1 \\
\hline Total domestic demand & 6.0 & -2.1 & -2.3 & 6.0 & 9.8 & 15.7 & 7.9 & -5.8 & -5.3 \\
\hline Private consumption & 4.2 & -2.8 & -1.5 & 6.2 & 6.9 & 12.9 & 4.6 & -0.4 & -4.0 \\
\hline Public consumption & 3.9 & 4.7 & 5.3 & 2.1 & 2.0 & 3.7 & 2.9 & 3.0 & 2.5 \\
\hline Gross fixed investment & 11.8 & -4.5 & -14.9 & 12.5 & 28.0 & 34.3 & 13.0 & -22.4 & -16.0 \\
\hline Export of goods and services & 4.2 & 7.4 & 3.8 & 1.6 & 8.4 & 7.2 & -5.6 & 11.6 & 9.8 \\
\hline Imports of goods and services & 8.6 & -9.1 & -2.5 & 10.8 & 14.4 & 29.4 & 8.8 & -9.8 & -4.7 \\
\hline Output gap 1/ & 2.9 & 1.4 & -2.2 & -2.6 & 1.8 & 5.2 & 3.3 & 1.3 & -2.6 \\
\hline \multicolumn{10}{|l|}{ Selected Indicators } \\
\hline Nominal GDP (bln ISK) & 682.1 & 769.8 & 812.3 & 839.7 & 926.5 & $1,021.5$ & $1,141.7$ & $1,230.2$ & $1,232.9$ \\
\hline Central bank gross reserves (bln ISK) & 34.2 & 36.6 & 37.2 & 58.1 & 65.6 & 67.3 & 167.8 & $\ldots$ & $\ldots$ \\
\hline Unemployment rate $2 /$ & 1.3 & 1.4 & 2.5 & 3.4 & 3.1 & 2.1 & 1.3 & 2.0 & 3.2 \\
\hline Real disposable income per capita & 1.0 & 1.6 & 3.6 & -1.3 & 3.7 & 6.5 & -5.6 & $\ldots$ & $\ldots$ \\
\hline Consumer price index & 5.1 & 6.6 & 4.8 & 2.1 & 3.2 & 4.0 & 6.8 & 4.8 & 3.3 \\
\hline Nominal wage index & 6.4 & 8.5 & 7.8 & 5.6 & 4.6 & 6.5 & 9.1 & 7.4 & 5.0 \\
\hline Nominal effective exchange rate 3 / & 0.0 & -15.7 & 2.5 & 6.2 & 1.8 & 10.4 & -10.8 & $\ldots$ & $\ldots$ \\
\hline Real effective exchange rate (CPI) 3 / & 2.7 & -12.5 & 6.2 & 6.3 & 2.8 & 12.8 & -6.8 & $\ldots$ & $\ldots$ \\
\hline Terms of trade & -2.4 & 0.3 & 0.6 & -4.1 & -1.3 & 1.0 & 3.6 & $\ldots$ & $\ldots$ \\
\hline \multicolumn{10}{|l|}{ Money and Credit } \\
\hline Deposit money bank credit (end-period) & 44.6 & 16.5 & 10.0 & 28.6 & 41.1 & 68.6 & 44.3 & $\ldots$ & $\ldots$ \\
\hline Domestic credit (end-period) & 43.8 & 12.4 & 7.1 & 21.6 & 36.0 & 44.2 & 31.8 & $\ldots$ & $\ldots$ \\
\hline Broad money (end-period) & 11.2 & 14.9 & 15.3 & 17.5 & 15.0 & 23.2 & 19.4 & $\ldots$ & $\ldots$ \\
\hline CBI policy rate (period average) & 10.4 & 10.9 & 8.4 & 5.4 & 6.1 & 9.4 & 12.4 & $\ldots$ & $\ldots$ \\
\hline \multicolumn{10}{|l|}{ Public Finance (in percent of GDP) } \\
\hline \multicolumn{10}{|l|}{ General government $4 /$} \\
\hline Revenue & 45.5 & 43.8 & 43.7 & 44.7 & 46.2 & 49.4 & 48.5 & 47.9 & 48.1 \\
\hline Expenditure & 43.8 & 44.5 & 46.2 & 47.5 & 46.0 & 44.2 & 43.2 & 44.8 & 49.6 \\
\hline Balance & 1.7 & -0.7 & -2.6 & -2.8 & 0.2 & 5.2 & 5.3 & 3.1 & -1.5 \\
\hline \multicolumn{10}{|l|}{ Balance of Payments (in percent of GDP) } \\
\hline Current account balance & -10.2 & -4.3 & 1.5 & -4.8 & -9.8 & -16.1 & -27.3 & -13.4 & -8.7 \\
\hline Trade balance (goods) & -5.5 & -0.8 & 1.7 & -1.9 & -3.9 & -9.1 & -13.7 & -4.9 & -3.2 \\
\hline Financial and capital account & 11.9 & 2.6 & -1.1 & 1.2 & 12.7 & 13.5 & 38.4 & 13.4 & 8.7 \\
\hline $\mathrm{o} / \mathrm{w}$ : reserve assets $5 /$ & 0.8 & 0.6 & -0.7 & -2.8 & -1.5 & -0.5 & -7.5 & 4.2 & 0.4 \\
\hline Net errors and omissions & -2.2 & -1.8 & 1.7 & -0.4 & 3.6 & -2.9 & 2.6 & -11.1 & 0.0 \\
\hline Gross external debt & 108.6 & 123.7 & 111.2 & 139.9 & 179.5 & 287.1 & 455.1 & 520.9 & 563.6 \\
\hline \multicolumn{10}{|l|}{ Central bank gross reserves (in months } \\
\hline of imports of goods and services) $6 /$ & 1.5 & 1.4 & 1.5 & 2.2 & 2.1 & 1.8 & 3.5 & $\ldots$ & $\ldots$ \\
\hline
\end{tabular}

Sources: Statistics Iceland; Central Bank of Iceland; Ministry of Finance; and staff estimates.

1/ Staff estimates. Actual minus potential output, in percent of potential output.

2/In percent of labor force.

3/ A positive (negative) sign indicates an appreciation (depreciation).

4/ National accounts basis.

5/ A positive (negative) sign indicates a decrease (increase) in gross official foreign reserves.

6/ Excluding imports from the construction of hydropower facility and smelters in 2003-04. 
Table 2. Iceland: Balance of Payments, 2000-2012 (in percent of GDP)

\begin{tabular}{|c|c|c|c|c|c|c|c|c|c|c|c|c|c|}
\hline & 2000 & 2001 & 2002 & 2003 & 2004 & 2005 & 2006 & 2007 & 2008 & 2009 & 2010 & 2011 & 2012 \\
\hline Current Account & -10.2 & -4.3 & 1.5 & -4.8 & -9.8 & -16.1 & -27.3 & -13.4 & -8.7 & -6.3 & -6.0 & -5.7 & -5.6 \\
\hline Balance on Goods & -5.5 & -0.8 & 1.7 & -1.9 & -3.9 & -9.1 & -13.7 & -4.9 & -3.2 & -2.6 & -2.5 & -2.4 & -2.5 \\
\hline Merchandise exports f.o.b. & 21.9 & 25.5 & 25.2 & 21.7 & 21.8 & 19.1 & 21.3 & 21.7 & 21.7 & 21.3 & 20.3 & 19.8 & 19.3 \\
\hline Merchandise imports f.o.b. & -27.4 & -26.3 & -23.4 & -23.6 & -25.8 & -28.2 & -35.0 & -26.6 & -24.9 & -23.8 & -22.8 & -22.2 & -21.7 \\
\hline Balance on Services & -1.7 & -0.2 & -0.1 & -1.1 & -1.6 & -3.2 & -4.5 & -3.0 & -2.3 & -2.1 & -2.0 & -1.9 & -1.9 \\
\hline Exports of services, total & 11.8 & 13.4 & 12.5 & 12.6 & 12.3 & 12.6 & 11.2 & 10.7 & 10.3 & 9.8 & 9.2 & 9.0 & 8.8 \\
\hline Imports of services, total & -13.5 & -13.6 & -12.5 & -13.7 & -13.9 & -15.7 & -15.8 & -13.7 & -12.6 & -11.9 & -11.3 & -10.9 & -10.7 \\
\hline Balance on Income & -2.9 & -3.2 & -0.2 & -1.7 & -4.2 & -3.7 & -8.8 & -5.4 & -3.0 & -1.4 & -1.3 & -1.2 & -1.0 \\
\hline Receipts & 1.7 & 2.2 & 3.3 & 3.4 & 3.6 & 8.9 & 14.7 & 24.8 & 34.2 & 38.7 & 38.6 & 38.4 & 38.8 \\
\hline Expenditures & -4.5 & -5.4 & -3.6 & -5.1 & -7.7 & -12.6 & -23.5 & -30.2 & -37.2 & -40.1 & -40.0 & -39.6 & -39.8 \\
\hline Current transfer, net & -0.1 & -0.1 & 0.1 & -0.1 & -0.1 & -0.2 & -0.2 & -0.2 & -0.2 & -0.2 & -0.2 & -0.2 & -0.2 \\
\hline Capital and Financial Account & 11.9 & 2.6 & -1.1 & 1.2 & 12.7 & 13.5 & 38.4 & 13.4 & 8.7 & 6.3 & 6.0 & 5.7 & 5.6 \\
\hline Capital transfer, net & 0.0 & 0.0 & 0.0 & 0.0 & 0.0 & -0.2 & -0.2 & -0.1 & -0.1 & -0.1 & -0.1 & -0.1 & -0.1 \\
\hline Financial Account & 12.0 & 2.5 & -1.1 & 1.2 & 12.8 & 13.7 & 38.5 & 13.6 & 8.8 & 6.4 & 6.1 & 5.8 & 5.7 \\
\hline Direct investment, net & -2.6 & -2.2 & -2.7 & -0.4 & -14.0 & -24.8 & -4.7 & 0.3 & -0.1 & 4.4 & 0.7 & -1.2 & -1.3 \\
\hline Abroad & -4.5 & -4.4 & -3.7 & -3.5 & -19.6 & -43.7 & -27.9 & -13.1 & -10.2 & -1.7 & -4.0 & -4.7 & -4.9 \\
\hline In Iceland & 2.0 & 2.2 & 1.0 & 3.0 & 5.6 & 18.9 & 23.3 & 13.4 & 10.1 & 6.2 & 4.7 & 3.5 & 3.7 \\
\hline Portfolio investment, net & 7.2 & 8.1 & 1.7 & 27.3 & 50.2 & 75.1 & 67.6 & 63.8 & 27.8 & 4.0 & 10.8 & 13.4 & 13.8 \\
\hline Assets & -6.5 & -0.6 & -3.6 & -5.4 & -12.5 & -28.9 & -20.5 & -33.8 & -23.9 & -7.7 & -6.4 & -12.5 & -8.2 \\
\hline Liabilities & 13.7 & 8.7 & 5.2 & 32.7 & 62.7 & 104.0 & 88.1 & 97.5 & 51.7 & 11.7 & 17.2 & 25.9 & 22.0 \\
\hline Other investment, net & 6.5 & -4.0 & 0.6 & -22.8 & -22.0 & -36.2 & -16.9 & -54.7 & -19.3 & -2.3 & -5.4 & -6.3 & -6.6 \\
\hline Assets & -1.0 & -6.1 & -3.7 & -18.6 & -25.7 & -67.2 & -68.1 & -63.9 & -19.5 & -4.5 & -10.5 & -12.2 & -13.0 \\
\hline Liabilities & 7.6 & 2.1 & 4.4 & -4.2 & 3.8 & 31.0 & 51.2 & 9.2 & 0.3 & 2.2 & 5.1 & 6.0 & 6.3 \\
\hline Reserve assets & 0.8 & 0.6 & -0.7 & -2.8 & -1.5 & -0.5 & -7.5 & 4.2 & 0.4 & 0.2 & 0.0 & -0.2 & -0.2 \\
\hline Net errors and omissions & -1.8 & 1.7 & -0.4 & 3.6 & -2.9 & 2.6 & -11.1 & 0.0 & 0.0 & 0.0 & 0.0 & 0.0 & 0.0 \\
\hline
\end{tabular}


Table 3. Iceland: Financial Soundness Indicators (as of year-end)

\begin{tabular}{|c|c|c|c|c|c|c|c|}
\hline & 2000 & 2001 & 2002 & 2003 & 2004 & 2005 & 2006 \\
\hline \multicolumn{8}{|l|}{ Capital adequacy $1 /$} \\
\hline Risk-based capital adequacy ratio (CAR) (in percent) & 9.8 & 11.4 & 12.2 & 12.3 & 12.8 & 12.8 & 15.1 \\
\hline CAR excluding subordinated loans (in percent) & 6.6 & 8.1 & 9.1 & 9.2 & 9.5 & 7.6 & 10.9 \\
\hline Tier 1 capital ratio (in percent) & 8.1 & 9.1 & 9.7 & 9.7 & 10.4 & 10.2 & 11.7 \\
\hline \multicolumn{8}{|l|}{ Asset quality } \\
\hline \multicolumn{8}{|l|}{ Credit institutions $2 /$} \\
\hline Total lending (in ISK billion) & 601.5 & 704.3 & 740.2 & 918.6 & $1,314.0$ & $2,203.0$ & $3,251.5$ \\
\hline thereof foreign currency loans (in percent) & 41.6 & 44.3 & 39.6 & 49.0 & 51.3 & 51.9 & 57.7 \\
\hline \multicolumn{8}{|l|}{ Sectoral credit concentration } \\
\hline Real estate loans (as percent of total loans) & 6.6 & 5.8 & 5.3 & $\ldots$ & $\ldots$ & $\ldots$ & $\ldots$ \\
\hline Loans to fisheries (as percent of total loans) & 22.9 & 21.2 & 17.1 & 13.4 & 10.9 & 10.9 & 3.1 \\
\hline thereof foreign currency loans (in percent) & 86.5 & 86.8 & 87.0 & 90.1 & 90.3 & 84.0 & 91.4 \\
\hline Loans to households (as percent of total loans) & 27.5 & 25.5 & 26.3 & 20.1 & 23.5 & 24.6 & 21.7 \\
\hline thereof foreign currency loans (in percent) & 8.1 & 10.4 & 8.6 & 4.1 & 7.0 & 5.2 & 10.4 \\
\hline Loans to businesses (as percent of total loans) & 65.2 & 64.2 & 62.6 & 61.9 & 59.1 & 50.5 & 50.9 \\
\hline thereof foreign currency loans (in percent) & 55.6 & 54.7 & 49.4 & 56.9 & 57.1 & 54.1 & 60.1 \\
\hline Loans to retail and services (as percent of total loans) & 29.4 & 30.0 & 32.7 & 35.5 & 37.7 & 33.4 & 34.9 \\
\hline thereof foreign currency loans (in percent) & 37.0 & 36.1 & 33.7 & 49.9 & 51.6 & 50.0 & 55.3 \\
\hline Loans to manufacturing et. al. (as percent of total loans) $3 /$ & 12.9 & 13.0 & 12.7 & 12.3 & 10.0 & 7.1 & 9.7 \\
\hline thereof foreign currency loans (in percent) & 43.0 & 45.3 & 39.2 & 42.1 & 43.4 & 42.4 & 63.0 \\
\hline Foreign sector (as percent of total loans) & $\ldots$ & 3.6 & 6.2 & 12.3 & 14.6 & 22.8 & 25.0 \\
\hline thereof foreign currency loans (in percent) & $\ldots$ & 99.4 & 78.6 & 91.2 & 96.1 & 96.6 & 95.9 \\
\hline Non-performing loans (NPL) as percent of total loans $1 / 4$ / & 1.5 & 2.0 & 2.6 & 2.1 & 0.9 & 1.1 & 0.8 \\
\hline Total provisions as percent of average loans $1 /$ & 0.8 & 1.2 & 1.2 & 1.4 & 0.8 & 0.3 & 0.3 \\
\hline Leverage ratio (equity as percent of total assets) $1 /$ & 6.2 & 6.5 & 7.2 & 7.1 & 7.1 & 7.4 & 7.8 \\
\hline \multicolumn{8}{|l|}{ Borrowing entities } \\
\hline \multicolumn{8}{|l|}{ Debt-equity ratios } \\
\hline All listed companies (except financial companies) & 2.3 & 2.3 & 1.7 & 1.8 & 2.1 & 1.9 & 2.5 \\
\hline Fisheries companies & 2.6 & 2.6 & 2.0 & 2.0 & 1.8 & 2.4 & 3.1 \\
\hline Manufacturing companies & 1.5 & 1.4 & 1.4 & 1.6 & 1.5 & 2.2 & 2.5 \\
\hline IT companies & 1.8 & 1.4 & 1.1 & 1.0 & 1.9 & 2.0 & 4.2 \\
\hline Retail, services, and construction companies & 1.9 & 2.0 & 1.5 & 1.4 & 3.2 & 1.6 & 3.8 \\
\hline \multicolumn{8}{|l|}{ Corporate profitability (EBITDA/turnover, in percent) } \\
\hline All listed companies (except financial companies) & 7.8 & 10.2 & 11.9 & 11.1 & 11.2 & 10.1 & 11.1 \\
\hline Fisheries companies & 17.4 & 27.1 & 24.0 & 21.3 & 17.5 & 18.7 & 22.9 \\
\hline Manufacturing companies & 12.5 & 13.4 & 12.9 & 11.0 & 19.0 & 15.9 & 15.3 \\
\hline IT companies & 9.0 & 10.2 & 27.2 & 23.4 & 13.9 & 9.3 & 8.6 \\
\hline Retail, services, and construction companies & 7.9 & 5.6 & 7.5 & 10.5 & 12.1 & 12.1 & 7.4 \\
\hline Household indebtedness (debt/disposable income, in percent) & 165.4 & 176.9 & 182.4 & 172.0 & 183.5 & 214.7 & 216.0 \\
\hline \multicolumn{8}{|l|}{ Management soundness $1 /$} \\
\hline \multicolumn{8}{|l|}{ Expense ratios } \\
\hline Operating expenses as percent of net operational revenue & 65.7 & 66.7 & 59.4 & 55.0 & 45.1 & 35.8 & 37.0 \\
\hline Staff costs as percent of net operational revenue & 32.9 & 33.8 & 30.9 & 29.4 & 23.9 & $\ldots$ & $\ldots$ \\
\hline \multicolumn{8}{|l|}{ Earnings and profitability $1 /$} \\
\hline Return on assets (after taxes, in percent) & 0.7 & 0.8 & 1.1 & 1.3 & 1.8 & 2.3 & 2.6 \\
\hline Return on equity (after taxes) & 10.7 & 13.5 & 18.1 & 22.1 & 30.9 & 41.7 & 39.1 \\
\hline Interest margin (as percent of total revenue) & 54.5 & 63.8 & 51.4 & 44.2 & 40.7 & 39.7 & 37.9 \\
\hline Fees and commissions (as percent total revenue) & 31.0 & 32.6 & 26.2 & 25.0 & 21.3 & 24.1 & 26.1 \\
\hline Value adjustments of other financial operations (as percent of total revenue) & $(1.2)$ & $(5.8)$ & 12.1 & 22.7 & 24.7 & 26.5 & 29.8 \\
\hline Dividends from shares and other holdings (as percent of total revenue) & 5.9 & 4.0 & 2.7 & 3.2 & 3.9 & 3.0 & $\ldots$ \\
\hline Other income (as percent of total revenue) & 9.8 & 5.3 & 7.6 & 4.9 & 9.3 & 6.7 & 6.2 \\
\hline
\end{tabular}

\section{CInternational Monetary Fund. Not for Redistribution}


Table 3. Iceland: Financial Soundness Indicators (continued) (as of year-end)

\begin{tabular}{|c|c|c|c|c|c|c|c|}
\hline & 2000 & 2001 & 2002 & 2003 & 2004 & 2005 & 2006 \\
\hline \multicolumn{8}{|l|}{ Liquidity } \\
\hline Central bank credit to banks (end of period, in ISK billion) & 46.9 & 68.7 & 73.7 & 25.0 & 37.5 & 87.7 & 120.0 \\
\hline Deposits to $M 3$ ratio & 1.0 & 1.0 & 1.0 & 1.0 & 1.0 & 1.1 & 1.0 \\
\hline Loans-to-deposits ratiom & 2.1 & 2.1 & 1.9 & 1.9 & 2.4 & 3.2 & 2.8 \\
\hline \multicolumn{8}{|l|}{ Liquidity ratio (cash and short-term assets/ } \\
\hline demand and short-term liabilities) & 1.2 & 1.2 & 1.2 & 1.2 & 1.3 & 1.5 & 2.0 \\
\hline \multicolumn{8}{|l|}{ Measures of secondary market liquidity: } \\
\hline Interbank FX market turnover (Kr. Billions) & 768.0 & 1218.0 & 834.4 & 1185.6 & 949.9 & 2077.5 & 4421.6 \\
\hline Interbank domestic market turnover (Kr. Billions) & 524.3 & 426.1 & 420.8 & 578.9 & 1073.3 & 1579.1 & 1646.8 \\
\hline \multicolumn{8}{|l|}{ Market-based indicators: } \\
\hline Stock market index (ICEX-15; y-o-y change, in percent) & -19.3 & -11.2 & 16.7 & 56.4 & 58.9 & 64.7 & 16.0 \\
\hline Residential housing prices (y-o-y increase, in percent) & 13.3 & 3.1 & 7.5 & 9.1 & 23.3 & 31.0 & 5.6 \\
\hline Commercial property prices ( $y-0-y$ increase, in percent) (between yearly averages & 16.3 & -2.8 & -12.6 & 11.6 & 6.9 & 12.6 & 35.0 \\
\hline Market capitalization at year-end (as a percent of GDP) & 59.5 & 57.0 & 68.2 & 81.3 & 126.2 & 182.3 & 340.8 \\
\hline Turnover rate (trading/market capitalization) (12 month trading) & 50.0 & 32.3 & 60.7 & 84.0 & 66.6 & 66.2 & 84.6 \\
\hline \multicolumn{8}{|l|}{ Credit ratings } \\
\hline Moody's short-term 1/ $2 /$ & $\mathrm{P} 1-\mathrm{P} 2$ & P1-P2 & $\mathrm{P} 1-\mathrm{P} 2$ & $\mathrm{P} 1$ & $\mathrm{P} 1$ & $\mathrm{P} 1$ & P1 \\
\hline Moody's long-term 1/ 2/ & A2-A3 & A2-A3 & A2-A3 & A1-A3 & A1-A3 & $\mathrm{A} 1-\mathrm{A} 2$ & Aa3 \\
\hline Fitch short-term 1/ 2/ & $\ldots$ & $\mathrm{F} 1$ & F1 & $\mathrm{F} 1$ & $\mathrm{~F} 1$ & $\mathrm{~F} 1$ & $\mathrm{~F} 1$ \\
\hline Fitch long-term 1/ 2/ & $\ldots$ & A & A & A & A & A & A \\
\hline $\begin{array}{l}\text { Sovereign yield spreads (spread between yields on } \\
\text { Icelandic and foreign trade-weighted 3-month T-bills, percentage points) }\end{array}$ & 6.3 & 7.9 & 3.1 & 2.8 & 5.3 & 6.2 & 12.1 \\
\hline \multicolumn{8}{|l|}{ Financial market structure: } \\
\hline \multicolumn{8}{|l|}{ Concentration ratios in the banking sector } \\
\hline Number of banks accounting for 25 percent of total assets $2 /$ & 1.0 & 1.0 & 1.0 & 1.0 & 1.0 & 1.0 & $\ldots$ \\
\hline Number of banks accounting for 75 percent of total assets $2 /$ & 3.0 & 4.0 & 4.0 & 3.0 & 3.0 & 3.0 & $\ldots$ \\
\hline Number of financial institutions (unconsolidated) & 29.0 & 29.0 & 29.0 & 28.0 & 28.0 & 28.0 & $\ldots$ \\
\hline Number of financial institutions (consolidated) $1 / 2 /$ & 10.0 & 10.0 & 10.0 & 10.0 & 10.0 & 10.0 & $\ldots$ \\
\hline
\end{tabular}

Sources: Financial Supervisory Authority and Central Bank of Iceland.

1/ Commercial banks and six (five from 2006) largest savings banks. In 2006, Sparisjodur velstjora and Sparisjodur Hafnarfjardar merged under the name of BYR-sparisjodur. Accordingly, figures for the savings banks at the end of 2006 are for the five largest savings banks.

2/ Deposit money banks. Figures from year 2003 onwards for sectoral breakdown of lendings is not comparable with the past because of new loan classifici 3/ Mining, manufacturing and construction.

4/The NPL ratios for 2005 and 2006 were not disclosed in the reports of most of the banks using IFRS for their annual accounts. The NPL ratios for these $t$ years are provided by the FME for the largest financial institutions ( 2 commercial banks and 6 largest savings banks) based on loans to customers excluding financial institutions.

\section{CInternational Monetary Fund. Not for Redistribution}


Table 4. Iceland: Summary Operations of the General Government, 2003-08 1/ (in percent of GDP)

\begin{tabular}{|c|c|c|c|c|c|c|c|c|}
\hline & \multirow{2}{*}{2003} & \multirow{2}{*}{2004} & \multirow{2}{*}{2005} & \multirow{2}{*}{2006} & \multicolumn{2}{|c|}{2007} & \multicolumn{2}{|c|}{$\begin{array}{l}\text { Proj. } \\
2008\end{array}$} \\
\hline & & & & & MoF & IMF & MoF & IMF \\
\hline Total revenue & 44.7 & 46.2 & 49.4 & 48.5 & 49.2 & 47.9 & 47.3 & 48.1 \\
\hline $\begin{array}{l}\text { Current revenue } \\
\text { of which: }\end{array}$ & 42.8 & 44.3 & 47.6 & 46.7 & 47.3 & 46.1 & 45.4 & 46.1 \\
\hline Direct taxes & 17.3 & 19.6 & 21.1 & 21.3 & 21.7 & 21.2 & 21.5 & 22.2 \\
\hline Indirect taxes & 17.3 & 18.4 & 19.6 & 19.1 & 18.4 & 17.7 & 17.2 & 17.2 \\
\hline Interest income & 1.3 & 1.1 & 1.0 & 1.5 & 1.8 & 1.7 & 1.5 & 1.5 \\
\hline Other current income & 7.0 & 5.3 & 5.8 & 4.8 & 5.4 & 5.4 & 5.2 & 5.2 \\
\hline Capital revenue & 1.9 & 1.9 & 1.8 & 1.8 & 1.9 & 1.8 & 1.9 & 2.0 \\
\hline Total expenditure & 47.5 & 46.0 & 44.2 & 43.2 & 46.0 & 44.8 & 48.4 & 49.6 \\
\hline $\begin{array}{l}\text { Current expenditure } \\
\text { of which: }\end{array}$ & 43.0 & 41.3 & 40.3 & 39.4 & 41.8 & 40.7 & 42.2 & 43.2 \\
\hline Interest expenditure & 2.7 & 2.4 & 2.1 & 2.1 & 2.5 & 2.5 & 2.3 & 2.4 \\
\hline Capital expenditure & 4.5 & 4.7 & 3.9 & 3.8 & 4.2 & 4.1 & 6.2 & 6.4 \\
\hline Primary balance & -0.1 & 2.6 & 7.4 & 7.5 & 5.8 & 5.6 & 1.2 & 0.9 \\
\hline Overall balance & -2.8 & 0.2 & 5.2 & 5.3 & 3.2 & 3.1 & -1.1 & -1.5 \\
\hline \multicolumn{9}{|l|}{ Debt position } \\
\hline General government gross debt & 40.9 & 34.5 & 25.5 & 31.5 & 31.5 & 26.1 & $\ldots$ & 27.6 \\
\hline General government net debt & 23.2 & 20.9 & 9.5 & 7.9 & 9.2 & 2.5 & $\ldots$ & 4.0 \\
\hline \multicolumn{9}{|l|}{ Cyclically adjusted $2 /$} \\
\hline Primary revenue & 43.5 & 45.0 & 48.1 & 46.9 & $\ldots$ & 46.1 & $\ldots$ & 46.6 \\
\hline Primary expenditure & 43.7 & 44.4 & 44.2 & 42.4 & $\ldots$ & 42.9 & $\ldots$ & 46.0 \\
\hline Primary balance & -0.2 & 0.7 & 3.9 & 4.5 & $\ldots$ & 3.2 & $\ldots$ & 0.7 \\
\hline Total revenue & 44.7 & 46.1 & 49.2 & 48.4 & $\ldots$ & 47.9 & $\ldots$ & 48.1 \\
\hline Total expenditure & 46.3 & 46.8 & 46.5 & 44.6 & $\ldots$ & 45.4 & $\ldots$ & 48.3 \\
\hline Overall balance & -1.6 & -0.7 & 2.7 & 3.8 & $\ldots$ & 2.5 & $\ldots$ & -0.2 \\
\hline \multicolumn{9}{|l|}{ Memorandum items: } \\
\hline Real public consumption growth $3 /$ & 3.9 & 2.9 & 4.5 & 4.7 & 6.8 & 5.7 & 2.9 & 2.5 \\
\hline Output gap 4/ & -2.6 & 1.8 & 5.2 & 3.3 & $\ldots$ & 1.3 & $\ldots$ & -2.6 \\
\hline
\end{tabular}

Sources: Ministry of Finance; and Fund staff estimates and calculations.

1/ Official forecast of the Ministry of Finance as of April 2006.

2/ In percent of potential GDP.

3/ Change in percent, deflated by CPI inflation.

4/ Actual output less potential in percent of potential. 
Table 5. Iceland. Medium-term Scenario, 2003-12

(Percentage change, unless otherwise indicated)

\begin{tabular}{|c|c|c|c|c|c|c|c|c|c|c|}
\hline & 2003 & 2004 & 2005 & 2006 & 2007 & 2008 & 2009 & 2010 & 2011 & 2012 \\
\hline Real GDP & 2.7 & 7.6 & 7.2 & 2.6 & 2.1 & -0.1 & 1.8 & 3.7 & 3.4 & 3.2 \\
\hline Real domestic demand & 6.0 & 9.8 & 15.7 & 7.9 & -5.8 & -5.3 & -2.0 & 1.2 & 1.9 & 2.4 \\
\hline Private consumption & 6.2 & 6.9 & 12.9 & 4.6 & -0.4 & -4.0 & -2.0 & 1.8 & 2.0 & 2.3 \\
\hline Public consumption & 2.1 & 2.0 & 3.7 & 2.9 & 3.0 & 2.5 & 2.5 & 2.5 & 2.5 & 2.5 \\
\hline Fixed investment & 12.5 & 28.0 & 34.3 & 13.0 & -22.4 & -16.0 & -7.0 & -2.0 & 1.0 & 3.0 \\
\hline Change in stocks $1 /$ & -0.3 & 0.1 & 0.0 & 1.6 & 0.0 & 0.0 & 0.0 & 0.0 & 0.0 & 0.0 \\
\hline Net exports $1 /$ & -3.2 & -2.4 & -9.2 & -6.3 & 8.9 & 5.7 & 3.8 & 2.5 & 1.5 & 0.9 \\
\hline Exports & 1.6 & 8.4 & 7.2 & -5.6 & 11.6 & 9.8 & 7.0 & 4.7 & 4.0 & 3.0 \\
\hline Imports & 10.8 & 14.4 & 29.4 & 8.8 & -9.8 & -4.7 & -2.4 & -1.4 & 0.4 & 1.1 \\
\hline Current account 2/ & -4.8 & -9.8 & -16.1 & -27.3 & -13.4 & -8.7 & -6.3 & -6.0 & -5.7 & -5.6 \\
\hline \multicolumn{11}{|l|}{ Inflation } \\
\hline Consumer Prices & 2.1 & 3.2 & 4.0 & 6.8 & 4.8 & 3.3 & 2.7 & 2.5 & 2.5 & 2.5 \\
\hline \multicolumn{11}{|l|}{ Labor market } \\
\hline Employment & -0.5 & 1.3 & 1.9 & 5.3 & 0.6 & -0.1 & 1.3 & 1.2 & 1.0 & 0.6 \\
\hline Average unemployment rate & 3.4 & 3.1 & 2.1 & 1.3 & 2.0 & 3.2 & 2.9 & 2.7 & 2.5 & 2.5 \\
\hline \multicolumn{11}{|l|}{ Public finance } \\
\hline General government balance 2/ & -2.8 & 0.2 & 5.2 & 5.3 & 3.1 & -1.5 & -2.9 & -1.1 & -1.0 & -0.9 \\
\hline General government structural balance 2/ & -1.6 & -0.7 & 2.7 & 3.8 & 2.5 & -0.2 & -2.4 & -1.0 & -1.0 & -0.9 \\
\hline General government gross debt 2/ & 40.9 & 34.5 & 25.5 & 31.5 & 26.1 & 27.6 & 30.0 & 30.0 & 29.5 & 29.0 \\
\hline Output gap 3/ & -2.6 & 1.8 & 5.2 & 3.3 & 1.3 & -2.6 & -1.1 & -0.2 & 0.0 & 0.0 \\
\hline
\end{tabular}

Sources: $\mathrm{CBI}$; and IMF staff estimates.

1/ Contributions to growth

2/ In percent of GDP

$3 /$ In percent of potential output 


\section{Appendix I. Iceland: External Debt Sustainability}

Significant current account deficit, driven by investment projects plus the expansion of Icelandic firms and commercial banks abroad, resulted in a sharp increase in external debt, from about 140 percent of GDP in 2003 to almost 450 percent in 2006. A large part of the increase is explained by the increased debt of Icelandic banks ( 86 percent of GDP in 2003 and 373 percent in 2006). In net terms, debt has increased from 101 percent of GDP in 2003 to 203 percent in 2006, while the net international investment position has deteriorated from -63 percent of GDP in 2003 to -122 percent in 2006.

Under the baseline scenario, the level of net external debt will increase further and stabilize below 240 percent of GDP. While various shocks could drive debt up further by some 20 percentage points, a 30 percent depreciation in real exchange rate in 2008 could increase the level of net debt to 364 percent of GDP. However, it should be noted that the baseline scenario already assumes a return of the real exchange rate to its equilibrium level with most of the depreciation occurring in 2007-09 (overall misalignment is estimated to be between 15 and 25 percent, see Box 2). While high external indebtedness raises concerns about Icelandic companies' ability to service debt, the discussions with the authorities and private sector representatives indicated that appropriate strategies have been put in place (see paragraphs 5, 6, 16, and 17 of this report).

One could argue, however, that the net external debt does not produce an accurate picture given large equity holdings by Icelandic companies. Indeed, under the same scenario IIP would deteriorate less, from -135 percent of GDP to -186 .

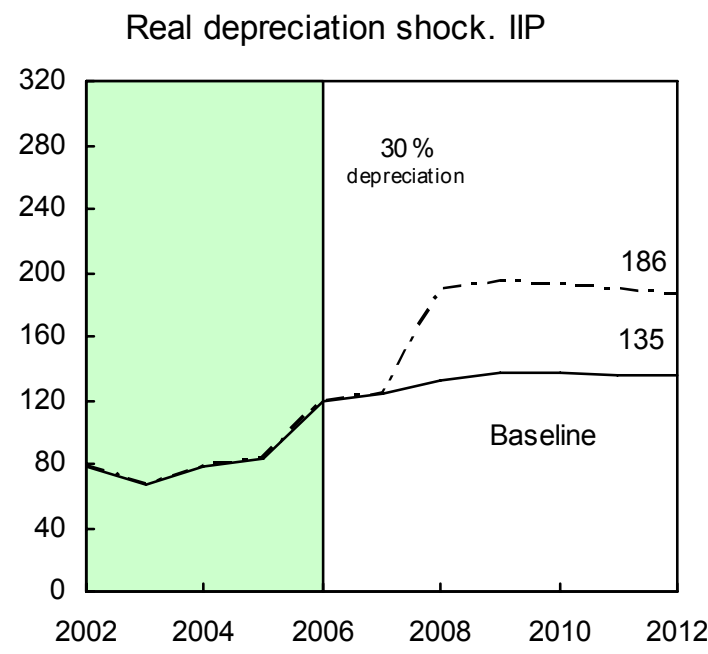

An additional caveat is measurement imperfections that get exacerbated when stocks are sizeable and the composition of assets and liabilities differ. Direct investment and equity, which represent about 40 percent of Icelandic assets but only 15 percent of liabilities, are likely undervalued (recorded at book or transaction, rather than market, value). However, 
debt securities, 60 percent of liabilities, are more accurately measured. If equity and direct investment instruments (both on the assets and liabilities sides) were undervalued by a third, then IIP would be undervalued by a third as well.

\begin{tabular}{|c|c|c|}
\hline & Percent of GDP & Share \\
\hline Assets: & 395.8 & 100.0 \\
\hline Direct Investment and Equity & 163.7 & 41.4 \\
\hline Debt Securities & 24.3 & 6.2 \\
\hline Loans & 152.4 & 38.5 \\
\hline Trade credits, currency, deposits, reserves, etc & 55.4 & 14.0 \\
\hline Liabilities: & 518.1 & 100.0 \\
\hline Direct Investment and Equity & 78.3 & 15.1 \\
\hline Debt Securities & 311.9 & 60.2 \\
\hline Loans & 94.0 & 18.2 \\
\hline Trade credits, currency, deposits, etc & 33.9 & 6.5 \\
\hline IIP: & -122.4 & \\
\hline
\end{tabular}


Table A1. Iceland: External Debt Sustainability Framework, 2002-2012

(In percent of GDP, unless otherwise indicated)

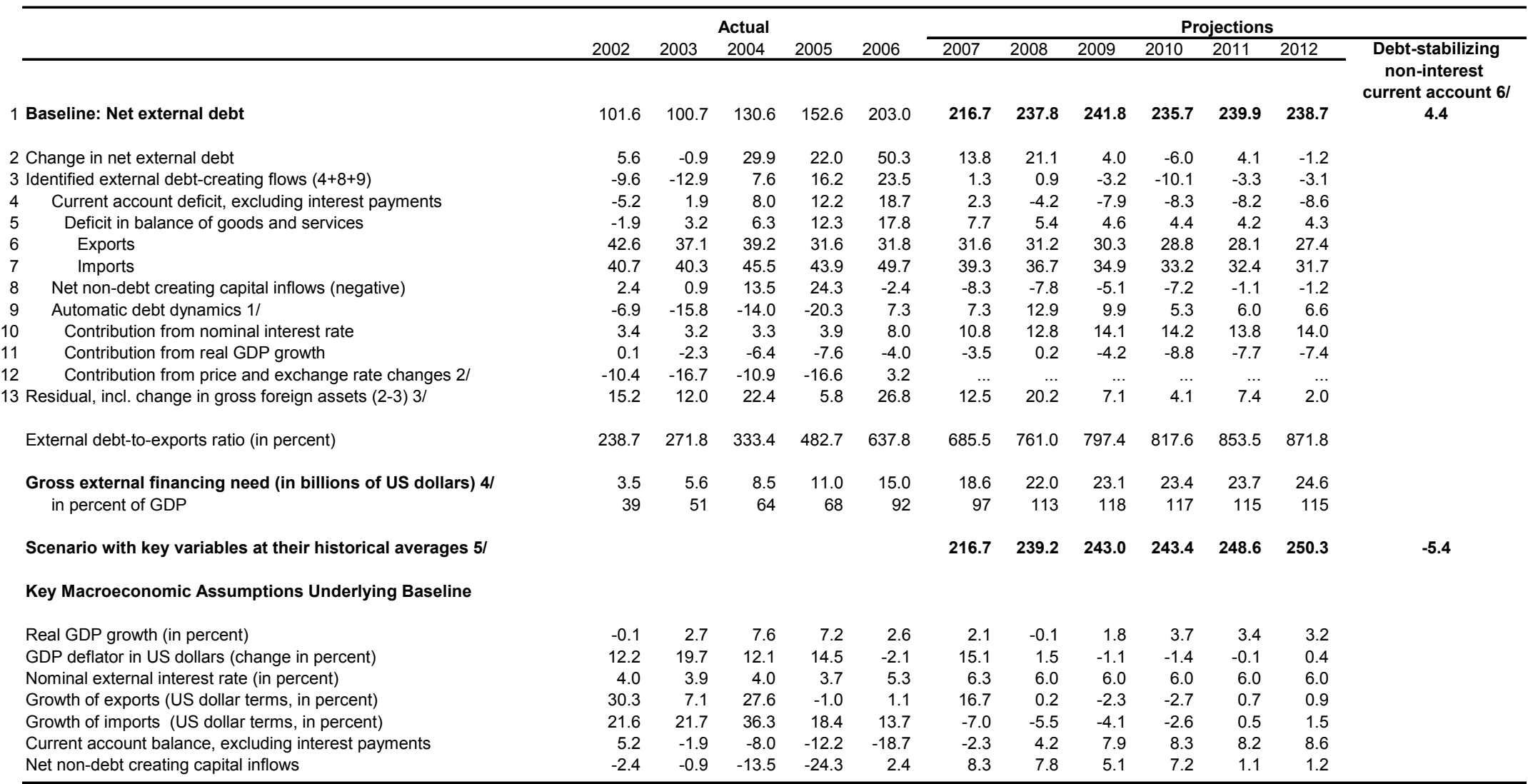

$1 /$ Derived as $[r-g-\rho(1+g)+\varepsilon \alpha(1+r)] /(1+g+\rho+g \rho)$ times previous period debt stock, with $r=$ nominal effective interest rate on external debt; $\rho=$ change in domestic GDP deflator in US dollar terms, $g=$ real GDP, growth rate, $\mathrm{e}=$ nominal appreciation (increase in dollar value of domestic currency), and $\mathrm{a}=$ share of domestic-currency denominated debt in total external debt.

$2 /$ The contribution from price and exchange rate changes is defined as $[-\rho(1+g)+\varepsilon \alpha(1+r)](1+g+\rho+g \rho)$ times previous period debt stock. $\rho$ increases with an appreciating domestic currency $(\varepsilon>0)$ and rising inflation (based on GDP deflator).

$3 /$ For projection, line includes the impact of price and exchange rate changes.

4/ Defined as current account deficit, plus amortization on medium- and long-term debt, plus short-term debt at end of previous period.

5/ The key variables include real GDP growth; nominal interest rate; dollar deflator growth; and both non-interest current account and non-debt inflows in percent of GDP.

6/ Long-run, constant balance that stabilizes the debt ratio assuming that key variables (real GDP growth, nominal interest rate, dollar deflator growth, and non-debt inflows in percent of GDP) remain at their levels of the last projection year. 
Table A2. Iceland: International Investment Position (in percent of GDP)

\begin{tabular}{|c|c|c|c|c|c|c|c|c|c|c|c|c|c|}
\hline & 2000 & 2001 & 2002 & 2003 & 2004 & 2005 & 2006 & 2007 & 2008 & 2009 & 2010 & 2011 & 2012 \\
\hline Assets & 44.4 & 53.5 & 50.5 & 84.4 & 124.7 & 245.0 & 395.8 & 473.9 & 526.1 & 530.7 & 530.4 & 535.1 & 535.0 \\
\hline Direct investment abroad & 8.2 & 11.3 & 12.6 & 14.7 & 26.6 & 62.2 & 82.9 & 90.0 & 100.0 & 100.0 & 100.0 & 100.0 & 100.0 \\
\hline Portfolio investment abroad & 25.5 & 25.1 & 19.7 & 31.2 & 40.4 & 68.1 & 105.1 & 131.3 & 155.0 & 160.0 & 160.0 & 165.0 & 165.0 \\
\hline Equity capital & 24.4 & 23.5 & 18.4 & 28.5 & 38.5 & 57.7 & 80.8 & 99.0 & 120.0 & 125.0 & 125.0 & 130.0 & 130.0 \\
\hline Debt securities & 1.1 & 1.6 & 1.3 & 2.8 & 1.9 & 10.4 & 24.3 & 32.3 & 35.0 & 35.0 & 35.0 & 35.0 & 35.0 \\
\hline Other investment abroad & 5.7 & 12.4 & 13.7 & 31.6 & 50.6 & 108.2 & 193.1 & 243.1 & 262.1 & 262.1 & 262.1 & 262.1 & 262.1 \\
\hline Reserve assers & 5.0 & 4.8 & 4.6 & 6.9 & 7.1 & 6.6 & 14.7 & 9.5 & 9.1 & 8.7 & 8.3 & 8.1 & 7.9 \\
\hline Liabilities & 112.3 & 131.5 & 119.8 & 147.1 & 192.3 & 328.8 & 518.1 & 601.0 & 661.8 & 670.5 & 670.6 & 674.7 & 673.3 \\
\hline Direct investment into Iceland & 6.2 & 9.2 & 8.2 & 10.1 & 13.8 & 28.0 & 47.2 & 57.2 & 67.2 & 72.2 & 74.0 & 74.0 & 74.0 \\
\hline Portfolio investment into Iceland & 51.0 & 61.2 & 58.3 & 89.8 & 136.4 & 233.8 & 343.1 & 415.9 & 466.7 & 470.4 & 468.7 & 472.7 & 471.4 \\
\hline Equity capital & 0.3 & 1.6 & 2.4 & 2.5 & 5.1 & 22.9 & 31.2 & 37.2 & 45.2 & 45.2 & 50.0 & 50.0 & 50.0 \\
\hline Debt securities & 50.6 & 59.7 & 55.9 & 87.4 & 131.2 & 210.8 & 311.9 & 378.8 & 421.6 & 425.2 & 418.7 & 422.7 & 421.4 \\
\hline Other investment into Iceland & 55.2 & 61.1 & 53.4 & 47.2 & 42.2 & 67.0 & 127.9 & 127.9 & 127.9 & 127.9 & 127.9 & 127.9 & 127.9 \\
\hline Net Assets & -67.9 & -78.0 & -69.3 & -62.7 & -67.6 & -83.7 & -122.4 & -127.1 & -135.7 & -139.8 & -140.3 & -139.5 & -138.3 \\
\hline Direct investment abroad & 2.1 & 2.1 & 4.4 & 4.6 & 12.9 & 34.2 & 35.7 & 32.8 & 32.8 & 27.8 & 26.0 & 26.0 & 26.0 \\
\hline Portfolio investment abroad & -25.5 & -36.2 & -38.6 & -58.6 & -96.0 & -165.7 & -237.9 & -284.6 & -311.7 & -310.4 & -308.7 & -307.7 & -306.4 \\
\hline Other investment abroad & -49.4 & -48.7 & -39.7 & -15.6 & 8.4 & 41.1 & 65.1 & 115.1 & 134.1 & 134.1 & 134.1 & 134.1 & 134.1 \\
\hline Reserve assers & 5.0 & 4.8 & 4.6 & 6.9 & 7.1 & 6.6 & 14.7 & 9.5 & 9.1 & 8.7 & 8.3 & 8.1 & 7.9 \\
\hline
\end{tabular}

Sources: $\mathrm{CBI}$; and IMF staff estimates. 
Figure A1. Iceland: External Debt Sustainability: Bound Tests 1/

(Net external debt in percent of GDP)

Baseline and historical scenarios

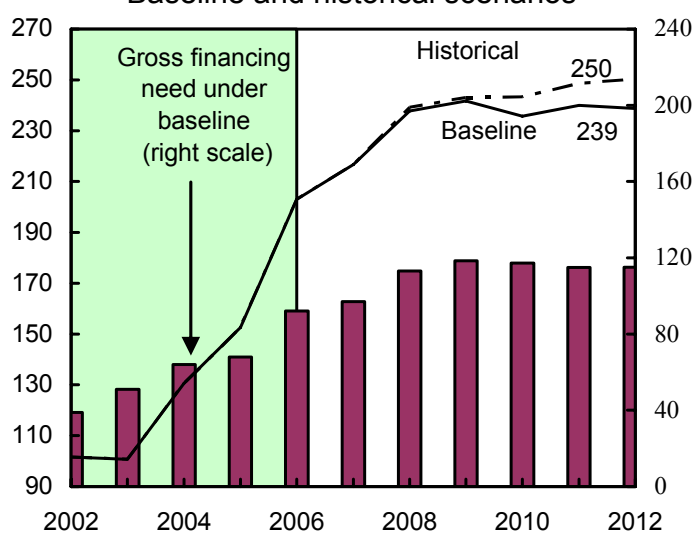

Growth shock (in percent per year)

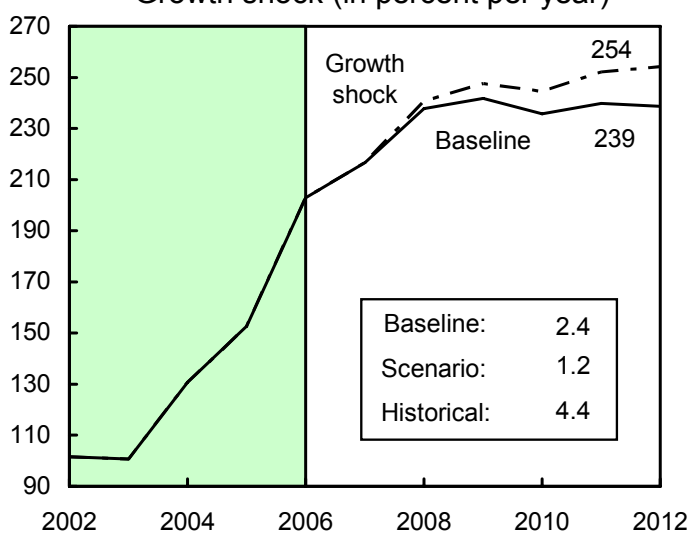

Combined shock 2/

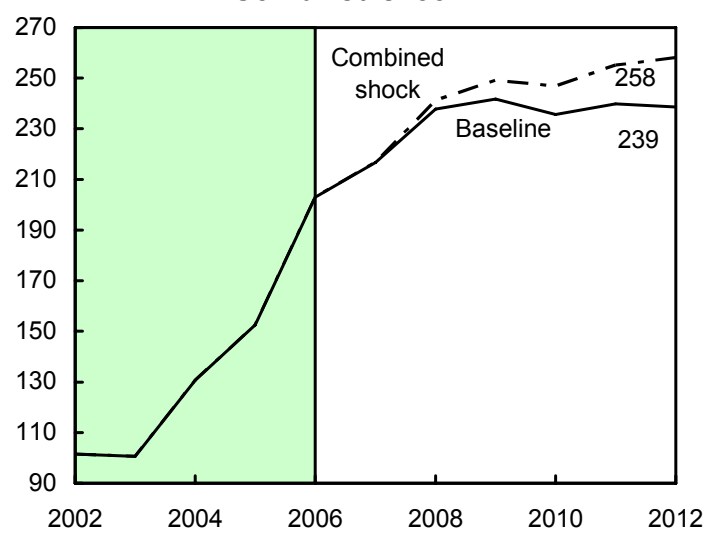

Interest rate shock (in percent)

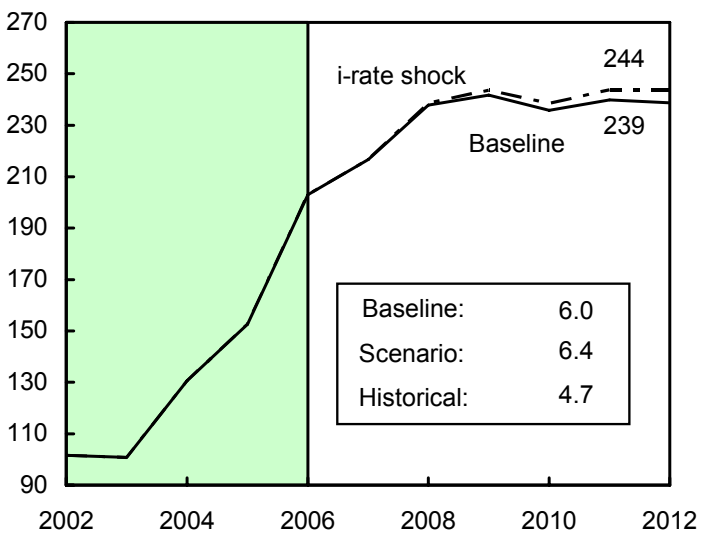

Non-interest current account shock (in percent of GDP)

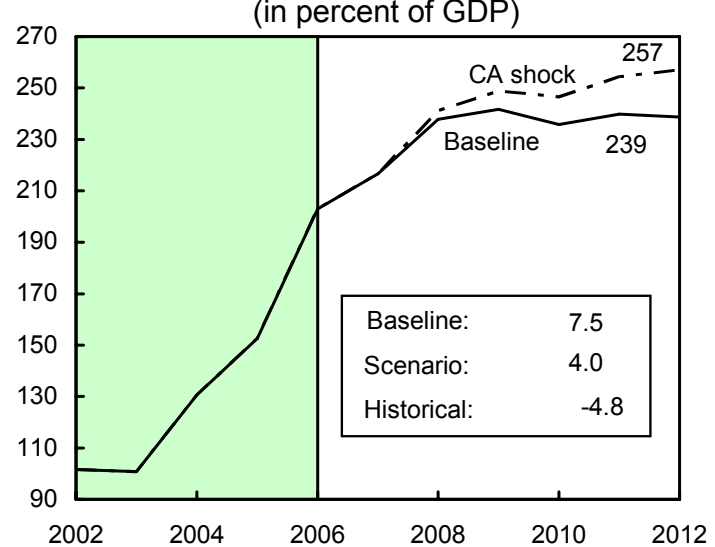

Real depreciation shock 3/

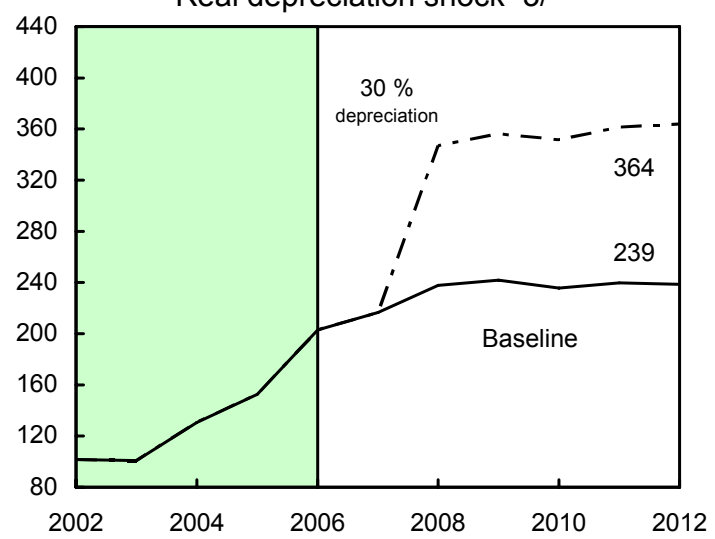

Sources: International Monetary Fund, Country desk data, and staff estimates.

$1 /$ Shaded areas represent actual data. Individual shocks are permanent one-half standard deviation shocks. Figures in the boxes represent average projections for the respective variables in the baseline and scenario being presented. Ten-year historical average for the variable is also shown.

2/ Permanent 1/4 standard deviation shocks applied to real interest rate, growth rate, and current account balance.

3/ One-time real depreciation of 30 percent occurs in 2008. 


\section{INTERNATIONAL MONETARY FUND}

\section{ICELAND}

Staff Report for the 2007 Article IV Consultation-Informational Annex

Prepared by the European Department

July 26, 2007

Contents

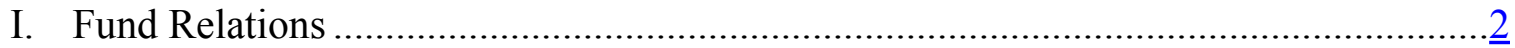

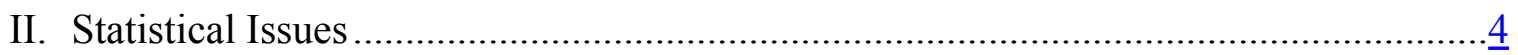




\section{Annex I. Iceland: Fund Relations}

(As of June 30, 2007)

The Article IV consultation discussions were held in Reykjavik during May 31-June 11, 2007. The mission team comprised Mr. Hunt (head), Mr. Annett, Mr. Tchaidze (all EUR), and Ms. Ong (MCM). Mr. Sigurgeirsson (Alternate Executive Director) attended some of the meetings. The staff met with the Prime Minister, the Minister of Finance, the Permanent Secretary in the Prime Minister's Office, the Governor of the Central Bank of Iceland, other senior officials from a wide range of public institutions, the major banks, and employer and employee federations.

Iceland has accepted the obligations of Article VIII, Sections 2, 3, and 4. The exchange rate is free of restrictions on payments and transfers for current international transactions other than restrictions notified to the Fund in accordance with Decision No. 144-(52/51).

The authorities published the mission's concluding statement which is available at http://www.imf.org/external/np/ms/2007/061107.htm and intend to publish the staff report.

I. Membership Status: Joined: December 27, 1945; Article VIII

II. General Resources Account:

Quota

Fund holdings of currency

Reserve position in Fund

Holdings Exchange Rate

$\begin{array}{cc}\text { SDR Million } & \text { \% Quota } \\ 117.60 & 100.00 \\ 99.01 & 84.19 \\ 18.59 & 15.81\end{array}$

$\begin{array}{cc}\text { SDR Million } & \text { \% Allocation } \\ 16.41 & 100.00 \\ 0.09 & 0.57\end{array}$

IV. Outstanding Purchases and Loans: None

V. Latest Financial Arrangements: None

VI. Projected Payments to the Fund (SDR Million; based on existing use of resources and present holdings of SDRs):

\begin{tabular}{|c|c|c|c|c|c|}
\hline & \multicolumn{5}{|c|}{ Forthcoming } \\
\hline & 2007 & 2008 & 2009 & 2010 & 2011 \\
\hline Principal & & & & & \\
\hline Charges/Interest & $\underline{0.35}$ & $\underline{0.69}$ & $\underline{0.69}$ & $\underline{0.69}$ & $\underline{0.69}$ \\
\hline Total & $\overline{0.35}$ & $\overline{0.69}$ & $\overline{0.69}$ & $\overline{0.69}$ & $\overline{0.69}$ \\
\hline
\end{tabular}


VII. Implementation of HIPC Initiative: Not applicable

VIII. Implementation of Multilateral Debt Relief Initiative (MDRI): Not applicable

IX. Exchange Rate Arrangements: Iceland adopted a floating exchange rate regime for the króna effective March 28, 2001.

Iceland continues to maintain exchange restrictions pursuant to UN sanction against Iraq (see EBD/03/115, 12/16/03).

X. Last Article IV Consultation:

Discussion for the 2006 Article IV Consultation were held in Reykjavik during May 8-15, 2006. The Staff Report (Country Report No. 06/296) was considered by the Executive Board on August 4, 2006. Article IV consultations with Iceland are currently held on the 12-month cycle.

XI. Technical Assistance: None

XII. Resident Representative: None 


\section{Annex II. Iceland: Statistical Issues}

Data provision to the Fund is adequate for surveillance purposes. Iceland subscribed to the Special Data Dissemination Standard (SDDS) in 1996. The Statistics Department (STA) prepared a data module of the Report on the Observance of Standards and Codes (data ROSC) that was published on November 22, 2005.

Data on a wide range of economic and financial variables are provided to the Fund in a timely manner during and between consultations. In addition to periodic press releases, statistical information is disseminated to the public through a range of monthly, quarterly, and annual publications by three main institutions (The Central Bank of Iceland (CBI), the Ministry of Finance, and Statistics Iceland), and is increasingly available on their internet sites. Provision of electronic data in English has improved substantially in recent years, especially from Statistics Iceland.

Iceland is in observance of the SDDS since June 30, 2004, meeting the specifications for coverage, periodicity, and timeliness, but uses a flexibility option on the timeliness and periodicity for the production index and the producer price index (PPI). Iceland generally meets the requirements regarding advance release calendars. However, there are some delays in the dissemination of data on central government operations and central government debt, and the advance release dates posted for these data categories are tentative. Also, summary methodology statements in a number of data categories are neither provided nor posted on the IMF's Dissemination Standards Bulletin Board.

As regards the national accounts data, the authorities shifted to ESA95 in August 2000 and revised the corresponding time series back to 1990. Another revision was carried out in 2002 going back only to 1997.

The authorities publish Treasury returns on a monthly basis, and quarterly and annual data on the general government balance. Iceland reports government finance statistics in accordance with the GFSM 2001 framework in the GFS Yearbook, and is an up-to-date contributor to the International Financial Statistics (IFS).

Iceland's balance of payments data deviate from the IMF's Balance of Payments Manual, fifth edition (BPM5) in certain respects. In particular, the CBI follows the methodology applied by the European Central Bank (ECB) for the calculation of income payable by collective investment institutions (e.g., mutual funds). Unlike the BPM5, the ECB's methodology includes portfolio investors' shares of retained earnings in the balance of payments statement.

Some other departures from BPM5 are: a) income on external debt is compiled on a due-forpayment basis, including between affiliated enterprises; b) debt between affiliated banks is 
not identified; c) banking sector loans are not classified separately from currency and deposits; d) in the international investment position, foreign direct investments are valued at book value; e) external debt is valued at face value; f) financial derivatives held by banks are not available as on-balance sheet items; and, g) domestic currency deposits held with banks by nonbank nonresidents are not recorded as part of external debt.

\section{Monetary and financial statistics}

The concepts and definitions broadly conform to the guidelines of the Monetary and Financial Statistics Manual (MFSM). Departing from the MFSM, monetary aggregates include deposits of the foreign sector and the central government; and the currency-linked and indexed bonds held by nonresidents are classified as domestic instead of foreign liabilities. Classification and sectorization are mostly in line with the MFSM, except that, in the accounts of other depository corporations (that is, commercial and savings banks), financial derivatives are off balance sheet and positions of nonfinancial public corporations are indistinguishably included as part of government; and, in the accounts of the CBI, fixed assets are off balance sheet and IMF accounts are included under other items net instead of as foreign liabilities. The basis for recording follows the MFSM, except that several banks report loans net of provisions and securities for investment are not at market value. The CBI has yet to commence reporting monetary data to STA using standardized report forms. 


\section{Iceland: Table of Common Indicators Required for Surveillance}

(As of July 6, 2007)

\begin{tabular}{|c|c|c|c|c|c|c|c|}
\hline & & Date & Frequency & Frequency & Frequency & Memo Items: & \\
\hline & $\begin{array}{c}\text { latest } \\
\text { observation }\end{array}$ & received & Data $^{6}$ & of ${ }_{\text {Reporting }}^{6}$ & publication $^{6}$ & $\begin{array}{c}\text { Data Quality - } \\
\text { Methodological } \\
\text { soundness }^{7} \\
\end{array}$ & $\begin{array}{l}\text { Data Quality - } \\
\text { Accuracy and } \\
\text { reliability } \\
\end{array}$ \\
\hline Exchange Rates & Jun 2007 & Jul 2007 & $\mathrm{D}$ and $\mathrm{M}$ & $\mathrm{D}$ and $\mathrm{M}$ & $\mathrm{D}$ and $\mathrm{M}$ & & \\
\hline $\begin{array}{l}\text { International Reserve Assets and Reserve Liabilities } \\
\text { of the Monetary Authorities }{ }^{1}\end{array}$ & May 2007 & $6 / 15 / 2007$ & M & M & M & & \\
\hline Reserve/Base Money & May 2007 & $6 / 21 / 2007$ & M & M & M & \multirow{4}{*}{$\mathrm{LO}, \mathrm{O}, \mathrm{LO}, \mathrm{LO}$} & \multirow{4}{*}{$\mathrm{LO}, \mathrm{O}, \mathrm{O}, \mathrm{O}, \mathrm{O}$} \\
\hline Broad Money & May 2007 & $6 / 21 / 2007$ & M & M & M & & \\
\hline Central Bank Balance Sheet & Jun 2007 & $7 / 5 / 2007$ & M & M & M & & \\
\hline Consolidated Balance Sheet of the Banking System & May 2007 & $6 / 21 / 2007$ & M & M & M & & \\
\hline Interest Rates ${ }^{2}$ & $7 / 6 / 2007$ & $7 / 6 / 2007$ & $\mathrm{D}$ & $\mathrm{D}$ & $\mathrm{D}$ & & \\
\hline Consumer Price Index & Jun 2007 & $6 / 12 / 2007$ & M & M & M & $\mathrm{O}, \mathrm{O}, \mathrm{O}, \mathrm{O}$ & $\mathrm{O}, \mathrm{O}, \mathrm{O}, \mathrm{O}, \mathrm{O}$ \\
\hline $\begin{array}{l}\text { Revenue, Expenditure, Balance and Composition of } \\
\text { Financing }{ }^{3} \text { - General Government }{ }^{4}\end{array}$ & 2006 & $4 / 24 / 2007$ & A & A & A & \multirow{2}{*}{$\mathrm{O}, \mathrm{LO}, \mathrm{O}, \mathrm{LO}$} & \multirow{2}{*}{$\mathrm{LO}, \mathrm{O}, \mathrm{O}, \mathrm{O}, \mathrm{O}$} \\
\hline $\begin{array}{l}\text { Revenue, Expenditure, Balance and Composition of } \\
\text { Financing }{ }^{3} \text { - Central Government }\end{array}$ & 2006 & $4 / 24 / 2007$ & A & A & A & & \\
\hline $\begin{array}{l}\text { Stocks of Central Government and Central } \\
\text { Government-Guaranteed Debt }\end{array}$ & 2006 & $6 / 19 / 2007$ & A & A & A & & \\
\hline External Current Account Balance & Q1, 2007 & $6 / 5 / 2007$ & Q & Q & Q & \multirow{2}{*}{$\mathrm{O}, \mathrm{O}, \mathrm{LO}, \mathrm{O}$} & \multirow{2}{*}{$\mathrm{LO}, \mathrm{O}, \mathrm{O}, \mathrm{O}, \mathrm{O}$} \\
\hline Exports and Imports of Goods and Services & May 2007 & $6 / 29 / 2007$ & M & M & M & & \\
\hline GDP/GNP & Q1, 2007 & $6 / 13 / 2007$ & Q & Q & Q & $\mathrm{O}, \mathrm{LO}, \mathrm{O}, \mathrm{LO}$ & LO, O, LO, LO, O \\
\hline Gross External Debt & Q1, 2007 & $6 / 5 / 2007$ & $\mathrm{Q}$ & $\mathrm{Q}$ & Q & & \\
\hline
\end{tabular}

${ }^{1}$ Includes reserve assets pledged or otherwise encumbered as well as net derivative positions.

${ }^{2}$ Both market-based and officially-determined, including discount rates, money market rates, rates on treasury bills, notes and bonds.

${ }^{3}$ Foreign and domestic financing.

${ }^{4}$ The general government consists of the central government (budgetary funds, extra budgetary funds, and social security funds) and state and local governments.

${ }^{5}$ Including currency and maturity composition.

${ }^{6}$ Daily (D), Weekly (W), Monthly (M), Quarterly (Q), Annually (A); Not Available (NA).

${ }^{7}$ Reflects the assessment provided in the data ROSC (published on November 22, 2005, and based on the findings of the mission that took place during February 1-15, 2005) for the dataset corresponding to the variable in each row. The assessment indicates whether international standards concerning concepts and definitions, scope, classification/sectorization, and basis for recording are fully observed (O); largely observed (LO); largely not observed (LNO); not observed (NO); and not available (NA).

${ }^{8}$ Same as footnote 7, except referring to international standards concerning (respectively) source data, assessment of source data, statistical techniques, assessment and validation of intermediate data and statistical outputs, and revision studies. 


\section{INTERNATIONAL MONETARY FUND}

Public Information Notice (PIN) No. 07/107 FOR IMMEDIATE RELEASE

August 29, 2007
International Monetary Fund

$70019^{\text {th }}$ Street, NW

Washington, D. C. 20431 USA

\section{IMF Executive Board Concludes 2007 Article IV Consultation with Iceland}

On August 22, 2007, the Executive Board of the International Monetary Fund (IMF) concluded the Article IV consultation with Iceland. ${ }^{1}$

\section{Background}

Aluminum-sector projects and structural changes in domestic financial markets spurred a sharp increase in domestic demand, boosting real GDP by more than 20 percent in four years until 2006. However, the boom left Iceland with a legacy of large macroeconomic imbalances.

The boom in private consumption was facilitated by easing household credit conditions, tax cuts, rapidly rising housing and equity wealth, and an appreciating real exchange rate. As a result, the output gap peaked at over 5 percent in 2005, declining only modestly in 2006. Unemployment fell to a historical low of 1 percent. Pressure in the goods and labor market pushed inflation well above the central bank's inflation target, peaking at 8 percent in 2006. On the external front, the current account deficit widened to a record 27 percent of GDP in 2006 . Net external debt exceeded 200 percent of GDP at the end of that year and household debt reached almost 250 percent of disposable income.

In 2007, the investment boom has largely run its course, inflation has fallen below 4 percent and the current account deficit is expected to decline significantly. However, private consumption has still not fallen to a sustainable level. A much-needed slowdown

\footnotetext{
${ }^{1}$ Under Article IV of the IMF's Articles of Agreement, the IMF holds bilateral discussions with members, usually every year. A staff team visits the country, collects economic and financial information, and discusses with officials the country's economic developments and policies. On return to headquarters, the staff prepares a report, which forms the basis for discussion by the Executive Board. At the conclusion of the discussion, the Managing Director, as Chairman of the Board, summarizes the views of Executive Directors, and this summary is transmitted to the country's authorities.
} 
appeared to be emerging over the course of 2006 as currency depreciation in the first half of that year raised import prices and hence slowed consumption. But this year a confluence of factors-Including renewed currency strength, tax cuts in early 2007, and continued house price appreciation-raised consumer confidence to historical highs around midyear, which may possibly delay both internal and external adjustment.

Monetary policy tightened during the upswing, with the policy rate rising to 13.3 percent in December 2006 where it has remained since. But monetary policy effectiveness was undermined by a competitive battle between the private banks and the publicly-owned Housing Financing Fund that eased household credit conditions. Consequently, the policy rate rose by more than would otherwise have been the case, leading to significant exchange rate appreciation owing to carry trade-related capital inflows. Fiscal policy did tighten in the upswing, but the fiscal stance eased in 2007.

Record current account deficits and credit downgrades early in 2007 caused little market disruption, in part reflecting a healthy financial sector. The exchange rate remained strong and confidence in the Icelandic banks stayed high as indicated by their equity prices and credit default swap spreads. Credit quality remains high, with low nonperforming loan ratios. Liquidity risk has declined, and cross and related-parties holdings of equity have been sold down. Financial supervisory stress tests suggested that banks have sufficient capital to withstand a combination of extreme credit and market shocks.

\section{Executive Board Assessment}

Executive Directors considered that the medium-term prospects for the Icelandic economy remain highly favorable, reflecting open and flexible markets, sound institutions, and skillful management of natural endowments. At the same time, record imbalances have built up during the recent boom, with elevated current account deficits, growing indebtedness, and persistently high consumer price inflation, all reflecting the unsustainable pace of domestic demand growth. Accordingly, Directors pointed to the need for greater macroeconomic stability, and called for policy measures to curb demand pressures.

Directors stressed that fiscal policy needed to be tighter than budgeted, especially as the 2007 tax cuts had eased the fiscal stance. They encouraged the authorities to constrain the growth in public consumption and slow the planned increase in public investment until domestic demand pressures have fully abated. At the same time, public sector wage growth should be restrained.

Directors called for the medium-term fiscal framework to be strengthened to increase its contribution to countercyclical stabilization and relieve some of the burden on monetary policy. They praised the medium-term expenditure framework underpinned by expenditure rules, but saw scope for improvement. In particular, Directors called on the authorities to ensure that the spending targets are met in each year, and noted that nominal targets based on the central bank's target rate of inflation could help ensure a 
countercyclical fiscal stance. Consideration should also be given to extending the rules to the local government sector, with explicit agreements between different levels of government.

Directors agreed that further tightening in monetary policy could be required to ease demand pressures and anchor inflation expectations. They noted that private consumption was expected to remain strong in 2007 , buoyed by tax cuts, a strong krona, as well as continuing income and asset price growth. Further, core and headline inflation continues to exceed the target. Directors welcomed recent enhancements in the central bank's communication strategy.

Directors generally considered that high domestic interest rates were largely responsible for the overvaluation of the exchange rate, which they considered temporary with the currency likely to depreciate over time to a more sustainable level as inflation returned to target. In this context, they stressed that monetary policy should guard against any second-round effects.

Directors called for prompt action on reforming the publicly-owned Housing Financing Fund. They noted that increased competition between the Housing Financing Fund and the banks is reducing the efficacy of monetary policy, necessitating greater increases in short-term interest rates than would otherwise be the case, with implications for capital flows and the exchange rate. While Directors welcomed recent reductions in loan-tovalue ratios at the Housing Financing Fund, they called on the government to permanently remove the distortion created by the Housing Financing Fund in the domestic financial market. Equitable access to mortgage funding throughout the country could still be guaranteed through the introduction of specifically targeted programs.

Directors welcomed the steps taken by banks to reduce vulnerabilities and increase resilience. They nonetheless stressed the need for risk management practices to continue evolving, especially as banks continue to expand and face increasing operational complexity, requiring a continued focus on credit risk. In particular, Directors noted that banks' foreign-currency lending to households had grown appreciably, which could become an important indirect credit risk.

Directors were encouraged by the outcome of stress tests suggesting that banks had adequate capital to withstand extreme credit and market shocks. Nonetheless, they called on the authorities to continue to monitor the situation carefully and to take further steps to improve the stress testing techniques employed. Directors also strongly supported the authorities' emphasis on cross-border collaboration in supervision and crisis management. 
Public Information Notices (PINs) form part of the IMF's efforts to promote transparency of the IMF's views and analysis of economic developments and policies. With the consent of the country (or countries) concerned, PINs are issued after Executive Board discussions of Article IV consultations with member countries, of its surveillance of developments at the regional level, of post-program monitoring, and of ex post assessments of member countries with longer-term program engagements. PINs are also issued after Executive Board discussions of general policy matters, unless otherwise decided by the Executive Board in a particular case. The staff report (use the free Adobe Acrobat Reader to view this pdf file) for the 2007 Article IV Consultation with Iceland is also available. 
Iceland: Selected Economic Indicators

\begin{tabular}{|c|c|c|c|c|c|c|}
\hline & 2002 & 2003 & 2004 & 2005 & 2006 & $20071 /$ \\
\hline \multicolumn{7}{|l|}{ Real Economy (change in percent) } \\
\hline Real GDP & -0.1 & 2.7 & 7.6 & 7.2 & 2.6 & 2.1 \\
\hline Domestic demand & -2.3 & 6.0 & 9.8 & 15.7 & 7.9 & -5.8 \\
\hline $\mathrm{CPI}$ & 4.8 & 2.1 & 3.2 & 4.0 & 6.8 & 4.8 \\
\hline Unemployment rate (in percent of labor force) & 2.5 & 3.4 & 3.1 & 2.1 & 1.3 & 2.0 \\
\hline Gross domestic investment (in percent of GDP) & 18.1 & 20.0 & 23.6 & 28.2 & 32.0 & 23.5 \\
\hline \multicolumn{7}{|l|}{ General Government Finances (in percent of GDP) } \\
\hline Financial balance $2 /$ & -2.6 & -2.8 & 0.2 & 5.2 & 5.3 & 3.1 \\
\hline Structural overall balance & -1.5 & -1.6 & -0.7 & 2.7 & 3.8 & 2.5 \\
\hline Gross debt & 42.3 & 40.9 & 34.5 & 25.5 & 31.5 & 26.1 \\
\hline \multicolumn{7}{|l|}{ Money and Credit (change in percent) } \\
\hline Deposit money bank credit (end of period) 3/ & & 28.6 & 41.1 & 68.6 & 44.3 & 25.7 \\
\hline Domestic credit (end of period) 3/ & & 21.6 & 36.0 & 44.2 & 31.8 & 20.3 \\
\hline Broad money (end of period) $3 /$ & & 17.5 & 15.0 & 23.2 & 19.4 & 28.2 \\
\hline $\mathrm{CBI}$ policy rate (period average, in percent) $3 /$ & & 5.36 & 6.10 & 9.36 & 12.43 & 14.25 \\
\hline \multicolumn{7}{|l|}{ Balance of Payments (in percent of GDP) } \\
\hline Trade balance & 1.6 & -3.0 & -5.5 & -12.3 & -18.2 & -7.9 \\
\hline Current account balance & 1.5 & -4.8 & -9.8 & -16.1 & -27.3 & -13.4 \\
\hline Financial and capital account balance & -1.1 & 1.2 & 12.8 & 13.7 & 38.5 & 13.6 \\
\hline Gross external debt & & 139.9 & 179.5 & 287.1 & 455.1 & 520.9 \\
\hline Reserves 4/ & 1.5 & 2.2 & 2.1 & 1.8 & 3.5 & 2.8 \\
\hline \multicolumn{7}{|l|}{ Fund Position (as of July 2, 2007) } \\
\hline Holdings of currency (in percent of quota) & & & & & 84.19 & $\ldots$ \\
\hline Holdings of SDRs (in percent of allocation) & & & & & 0.57 & $\ldots$ \\
\hline Quota (in millions of SDRs) & & & & & 117.60 & $\ldots$ \\
\hline \multicolumn{7}{|l|}{ Exchange Rate } \\
\hline Exchange rate regime & \multicolumn{6}{|c|}{ Floating Exchange Rate } \\
\hline Present rate (July 2,2007 ) 5/ & \multicolumn{6}{|c|}{113.5} \\
\hline Nominal effective rate (change in percent) & 2.5 & 6.2 & 1.8 & 10.4 & -10.8 & $\ldots$ \\
\hline Real effective rate (change in percent) & 6.2 & 6.3 & 2.8 & 12.8 & -6.8 & $\ldots$ \\
\hline
\end{tabular}

Sources: Statistics Iceland, Central Bank of Iceland, Ministry of Finance, and IMF staff estimates.

1/ Projection.

2/ National accounts basis.

$3 / 2007$ data as of May.

$4 /$ In months of imports of goods and services.

5 / Trade weighted index of the exchange rate as kronur per unit of foreign currency $(12 / 31 / 1991=100)$ 